\title{
COMENTARIOS AL DECRETO LEY 26122 SOBRE REPRESIÓN DE LA COMPETENCIA DESLEAL
}

\author{
Baldo Kresalja R.
}

\section{SUMARIO}

I. La disciplina de la competencia desleal: nociones introductorias .- 1.1 Evolución histórica; 1.1.1 Antecedentes; 1.1.2 Origen de la insțtución; 1.1.3 El modelo social .- 1.2 Competencia prohibida y competencia desleal -1.3 Relatividad del concepto de competencia desleal .- 1.4 Definición .- 1.5 La técnica jurídica de represión; 1.5.1 Represión mediante la aplicación del principio de la responsabilidad extracontractual; 1.5.2 Represión mediante ley especial; 1.5.2.1 Cláusula general; 1.5.2.2 Supuestos típicos - 1.6 Naturaleza y contenido de la acción de competencia desleal .- II. El decreto ley 26122 . - 2.1 Antecedentes .- 2.2 Ámbito territorial .- 2.3 Objeto de la protección .- 2.4 Relación de competencia - -2.5 Exigencia de daño - 2.6 Actos desleales graves y leves .- 2.7 Cláusula general prohibitiva .- 2.8 Supuestos concretos de competencia desleal; 2.8.1 Actos o conductas consistentes en aprovecharse del esfuerzo de otros participantes en el mercado; 2.8.1.1 Actos de confusión; 2.8.1.2 Imitación de iniciativas; 2.8.1.3 Actos de imitación; 2.8.1.4 Explotación de la reputación ajena; 2.8.1.5 Actos de comparación; 2.8.1.6 Copia no autorizada; 2.8.1.7 Violación de secretos; 2.8.2 Actos o conductas que constituyen ataques directos a otras empresas participantes en el mercado; 2.8.2.1 Inducción a la infracción contractual; 2.8.2.2 Actos de denigración; 2.8.3 Actos o conductas que inciden directamente en las posibilidades de actuación de los participantes en el mercado impidiendo el funcionamiento correcto del mismo; 2.8.3.1 Actos de engaño; 2.8.3.2 Violación de normas; 2.8.3.3 Discriminación .2.9 Pequeña cláusula general - -2.10 Acciones y procedimiento; 2.10.1 Legitimación activa; 2.10.2 Legitimación pasiva; 2.10.3 Acciones; 2.10.3.1 Acción declarativa; 2.10.3.2 Acción de cesación; 2.10.3.3 Acción de remoción; 2.10.3.4 Acción de rectificación; 2.10.4 Medidas cautelares .- 2.11 Sanciones .- 2.12 Nulidad .-2.13 Prescripción - 2.14 Acción de resarcimiento .- 2.15 Acción penal .- 2.16 Modelo de competencia subyacente . -2.17 Reflexión final .- Bibliografía. 
Durante los últimos tres años se han dictado un conjunto de normas jurídicas que tienen por objeto hacer más natural y menos trabada la actividad económica, liberalizándola, pero también buscando castigar aquellas actuaciones que se consideren contrarias al funcionamiento libre del mercado.

Dentro de ese grupo destacan los decretos legislativos $701,691,716$, referentes a la regulación de la libre competencia, la publicidad y la protección al consumidor, respectivamente. También el decreto legislativo 757, que ratifica y amplía la garantía constitucional de libre acceso al mercado, el decreto ley 26017 , sobre la propiedad industrial, y el decreto ley 26122 sobre represión de la competencia desleal, que es motivo de comentario en el presente artículo. Finalmente, debemos hacer mención al decreto ley 25868, que ha creado el INDECOPI (Instituto Nacional de Defensa de la Competencia y de la Protección de la Propiedad Intelectual), pues este organismo está encargado de resolver a nivel administrativo los conflictos que surgen de un importante número de actividades vinculadas con la vida empresarial y los negocios, en un diseño sui generis, imaginativo, y si bien sus frutos serán sólo posibles de conocer en el futuro, debe decirse que ha nacido bajo buenos auspicios.

Los dispositivos legales citados están destinados a tener una gran importancia en la vida económica y jurídica del país. Nos interesa resaltar, sin embargo, que los criticados - en exceso- preceptos constitucionales económicos de 1979 y la propuesta explícita para vivir en un Estado social y democrático de Derecho, resultado del consenso activo y no del mero acatamiento, han sido fundamento suficiente para las normas encaminadas a hacer realidad el funcionamiento de una economía social de mercado, en cuya concepción está siempre presente la preocupación para lograr el bien común, más allá de la legítima aceptación del éxito individual.

Antes de ingresar al análisis del decreto ley 26122 , creemos conveniente hacer una breve referencia al desarrollo histórico de la disciplina, así como plantear algunas consideraciones que son presupuesto necesario para entender a cabalidad el sentido de las normas encargadas de reprimir la deslealtad en la vida económica. 


\section{La disciplina de la competencia desleal: nociones introductorias}

\subsection{Evolución histórica}

\subsubsection{Antecedentes}

Gustavo Ghidini ha dicho que resulta equivocada aquella perspectiva histórico-jurídica que atribuye a las «reglas de competencia» existentes en el período de las corporaciones del Renacimiento, el carácter de precedente de la actual disciplina, puesto que estaban destinadas a tutelar los intereses de la corporación en su función reguladora y monopolizadora de la actividad de un cierto sector económico $-\mathrm{y}$ no de los empresarios en posición de autonomía-, así como los de la comunidad política interesada en salvaguardar la corporación. Esa normativa otorgaba preeminencia al interés público y constituía un freno a la competencia, pues buscaba garantizar o reservar una parte de la clientela y del elemento laboral. Puede afirmarse, por tanto, que en la Alta Edad Media había una «economía sin competencia», ya que sólo la corporación y/o el ente público local se encontraban legitimados para accionar, teniendo las sanciones carácter administrativo y penal (Ghidini, 7 a 14). En síntesis, en la Edad Media la normativa tiene carácter fragmentario y casi total ausencia de análisis doctrinal ${ }^{1}$, todo lo cual limita su interés como pretendido antecedente.

Pero el recuerdo de las corporaciones o gremios no es irrelevante pues sirve para penetrar en una de las particularidades fundamentales de la disciplina moderna: su carácter profesional, el ser fruto de la autorregulación, de un compromiso de intereses de categoría o de clase, que el ordenamiento estatal garantiza, y que paulatinamente iría pasando de un carácter igualitario (autorregulación corporativa) al afianzamiento de las empresas y grupos em-

1 La primera doctrina en materia de competencia desleal aparece a finales del siglo XV y es obra de teólogos; y las primeras disputas se refieren a la competencia entre docentes, la que se desarrollaba fuera de la organización corporativa y que, por tanto, no encontraba limitaciones intrínsecas, estando la licitud en función de los medios utilizados. S. Antonio (siglo XV) distingue según que la acción sea realizada in odium doctorum o por utilidad de los estudiantes y a petición suya. Como se comprenderá, estas disputas teológicas no tardaron en ser trasladadas al ámbito comercial (Nota 6, págs. 10, 11, Ghidini). 
presariales más fuertes, que terminarán imponiéndose como expresión «auténtica» de la ética profesional (Ghidini, 15, 16, 17).

Más tarde, el mercantilismo colocaría a las corporaciones en posición subordinada dentro del sistema económico, sometiéndolas a un efectivo control estatal, desplazándose el centro de la actividad hacia las «grandes manufacturas» ejercidas en régimen de autorización bajo el control del Estado, sistema bajo el que se asignan los sectores de mayor rentabilidad económica. En este sistema, fundado en el privilegio de la industria, no resulta posible el nacimiento del fenómeno concurrencial en el sentido moderno, y, por consiguiente, de un régimen que reprima la competencia desleal (Ghidini, 15 , notas 15 y 16 ).

Afirma Ghidini: «Como prueba de que en las relaciones económicas los conceptos de lícito e ilícito están en función de los intereses dominantes, puede observarse cómo en los orígenes del capitalismo liberal... la ausencia de cualquier tipo de frenos estatales constituía exigencia del sistema, a fin de posibilitar la creación de fuertes núcleos empresariales. La intervención del Estado (tanto a nivel jurisprudencial como legislativo) se producirá -es decir, será solicitada por los grupos empresariales más potentes- una vez consolidado un aparato industrial suficientemente fuerte como para no temer - sino más bien exigir - la intervención estatal en defensa de las posiciones adquiridas en el mercado» (Ghidini, 16, 17, 18).

Como veremos a continuación, las modernas normas que reprimen la competencia desleal, que surgieron con la madurez - y no desde el nacimiento- de la economía liberal, tienen diferencias sustantivas en cuanto a sus presupuestos, finalidad y criterios de aplicación con las «reglas de competencia» del sistema corporativo, por lo que, con independencia de coincidencias nominales, los dos fenómenos normativos corresponden a dos institutos heterogéneos en un plano de discontinuidad sustancial (Ghidini, 11; Menéndez, 26, 27).

\subsubsection{Origen de la institución}

La revolución industrial inglesa, en lo económico, y la revolución francesa, en lo político - como en muchos otros casos en el derecho moderno-, fueron las causas que dieron origen a la institución. Dice Bercovitz: «La regu- 
lación moderna contra la competencia desleal surge en el siglo XIX de la mano del liberalismo económico. Ello es así porque una de las conquistas de la Revolución francesa consiste en la denominada libertad de industria y de comercio, dicho en otros términos, en la libertad de competir. Libertad que en etapas históricas anteriores no existía, debido principalmente a la rígida implantación de los gremios» (Bercovitz, 1).

Conforme las personas se dedicaban al libre ejercicio de actividades económicas, se puso de manifiesto la necesidad de evitar que los participantes poco escrupulosos perjudicaran a sus competidores mediante actuaciones incorrectas o desleales. Por ello surge a lo largo del siglo pasado la protección contra la competencia desleal; específicamente en Francia, basada en la interpretación del artículo $1382^{\circ}$ del Código Civil napoleónico sobre la responsabilidad extracontractual. Posteriormente, en 1909 fue en Alemania en donde se pone en vigencia una ley específica sobre la materia (Bercovitz, 1).

La protección, tanto por la vía jurisprudencial —en Francia- como por la vía legislativa —en Alemania-, exigía que se cumplieran dos requisitos: que quien ejerciera la acción por competencia desleal tuviera el carácter de competidor del empresario autor de los actos incorrectos, y que tales actos pudieran perjudicarlo. Entonces, si no existía esta «relación de competencia» - concepto que ha perdido importancia hoy día, como veremos más adelante- no podía existir competencia desleal. En síntesis, la regulación tradicional trataba de proteger los intereses de los empresarios frente a sus competidores directos (Bercovitz, 1).

En esta primera etapa, siguiendo a Menéndez, puede hablarse de dos modelos: el primero, denominado modelo paleoliberal, que tuvo vigencia desde la Revolución francesa hasta la dación de la ley alemana de 1909, período en el que podemos decir, simplificando, que en Europa se consideró legítima cualquier iniciativa en el campo económico, siempre que no se infringieran los derechos exclusivos que otorgaba la propiedad industrial y no se violaran normas penales. Es en esta etapa donde el derecho sobre la marca se convierte en el «derecho piloto» en la formación de la disciplina de la competencia desleal. A este respecto, resulta significativo comprobar que en el derecho anglosajón la competencia desleal no sea, en definitiva, hasta hoy en día, más que el desarrollo de la acción de imitación y confu- 
sión de signos distintivos comerciales no registrados, denominada passing off (Menéndez, 31-33).

Ahora bien, la consolidación del régimen económico liberal a fines del siglo XIX reclama una protección general que reemplace a la disciplina fragmentaria, típica y penal del período anterior, muy vinculada a la propiedad industrial. Se ingresa así a un segundo modelo, el profesional, en el que la disciplina tendrá un carácter privado y estará encaminada a reprimir aquellas modalidades competitivas que los empresarios en su conjunto estiman incorrectas (Menéndez, 65).

Se recurre entonces a la técnica - hasta hoy vigente- de la cláusula general, cuyo paradigma es la ley alemana de 1909 , que pasa a convertirse en norma clave que se repite en las leyes posteriores. Dicha cláusula contiene una definición omnicomprensiva de todas las eventuales manifestaciones concretas de deslealtad, verdadera fórmula en blanco, en cuanto que remite a su vez a valoraciones sociales que han de ser verificadas por el juez en su calidad de intérprete: las buenas costumbres mercantiles, la probidad comercial, etc. Los intereses principalmente tutelados son los privados, los de los empresarios en sus relaciones recíprocas en el mercado. Durante esta etapa se considera que tanto los intereses del público como los de los consumidores se hallan suficientemente protegidos de una manera indirecta como reflejo de la protección a la empresa. Así, los competidores funcionarán como un "vengador vicario» de los intereses de los consumidores (Menéndez, 66, 67, 68). El autor y la víctima sólo pueden ser dos empresarios en directa relación de competencia.

La disciplina se despenaliza y privatiza y sus sanciones típicas se sitúan en los moldes del derecho privado: las acciones de cesación, de remoción y de daños y perjuicios (Menéndez, 68). Puede entonces afirmarse que la normativa no se presenta como una manifestación de una intervención estatal en los procesos concurrenciales, sino como un mero derecho de conflictos (Menéndez, 72).

\subsubsection{El modelo social}

En los años inmediatamente posteriores a la terminación de la segunda guerra mundial, se inicia en Europa un proceso de reorientación de la disciplina 
de la competencia desleal al producirse una quiebra en el postulado ideológico que afirmaba la coincidencia entre los intereses de los empresarios y el interés general, lo que trajo cambios en aspectos básicos como los referentes al objeto de protección, los criterios de enjuiciamiento de la deslealtad y la determinación de las prácticas reprimidas (Menéndez, 95, 96).

En efecto, y como dice Menéndez: «En relación con el objeto de protección se observa el paso de una concepción centrada en la tutela de los intereses individuales de los competidores a una concepción fundada en la protección del orden económico del mercado en función del interés privado de los competidores, el interés colectivo de los consumidores y el interés público del Estado. En el plano de los criterios de enjuiciamiento se advierte también una notable transformación: la deslealtad deja de ser primariamente entendida como un juicio de incorrección profesional, ensayado en atención a las normas morales o convencionales de la clase empresarial, para convertirse en un juicio de inadecuación a los principios del ordenamiento económico (libre competencia, tutela del consumidor, etc). Finalmente, en la cuestión relativa a las prácticas reprimidas se advierten asimismo algunos cambios importantes: ciertas actividades anteriormente consideradas como desleales (sirvan de ejemplo la publicidad comparativa o la invasión de zona de exclusiva), comienzan a permitirse en atención a los efectos beneficiosos que pueden producir desde el punto de vista de los intereses de los consumidores y del interés público en la conservación de un mercado altamente competitivo; por el contrario, ciertas prácticas permitidas (como pueden ser la venta bajo coste, la publicidad engañosa, o las ventas agresivas) se someten a una nueva estimación en respuesta a la primacía de los valores o intereses ahora dominantes» (Menéndez, 96).

El cambio operado obedece a la influencia de la legislación antitrust de origen norteamericano, en virtud de la cual se considera que el empresario no tiene sólo derecho a competir sino la obligación de hacerlo, y que si viola esta obligación realizando pactos o concertando comportamientos para no competir o restringir la competencia, entonces está actuando ilegalmente y su actuación debe ser sancionada. Como es lógico, esta regulación se basa en la idea de que el sistema competitivo de economía de mercado es el más eficiente para la atribución de los recursos económicos. Y si bien se sigue amparando al empresario competidor, el criterio fundamental es la defensa del funcionamiento competitivo del mercado (Bercovitz, 1, 2). 
Puede, pues, afirmarse que «lo que era un Derecho de conflictos interempresariales, es decir, una verdadera disciplina de cuerpo o de clase, se presenta cada vez más como un Derecho general de ordenación del mercado» (Menéndez, 101). Y no puede dejarse de considerar que esta iniciativa o formulación viene impuesta por la Constitución económica del Estado social, que decide intervenir en los procesos naturales del mercado para que la libertad económica no conduzca a una creciente monopolización y a la consiguiente negación del orden competitivo. A todo ello se suma el desarrollo, por parte del Estado, de una política de tutela reforzada del consumidor como parte débil de las relaciones del mercado (Menéndez, 97 a 99). En síntesis, se presentan dos factores decisivos que explican las nuevas orientaciones en esta materia: la asunción, por parte del Estado, de una política de defensa de la competencia, abandonada - hasta entonces- al libre juego de los sujetos económicos participantes en el mercado, así como de una política de tutela del consumidor confiada también hasta entonces al mercado (Menéndez, 97).

El objeto de protección propuesto por el «modelo social» del que venimos hablando es el orden económico de mercado, que se integra funcionalmente en un derecho general de la competencia, en el que la categoría del abuso del derecho parece ser la más adecuada para encuadrar dogmáticamente el acto de competencia desleal. Y debe decirse que no se trata de un abuso individual sino de un abuso institucional: «En otros términos, que el ejercicio de un derecho (el derecho a la libre iniciativa económica) no puede lesionar la finalidad de un instituto jurídico (la competencia) en el que funcionalmente se integra» (Menéndez, 110).

De lo anterior se colige que los criterios de enjuiciamiento deben aplicarse dentro del marco del sistema económico constitucionalizado, observándose las directrices político-económicas y político-sociales que emanan del mismo, las mismas que deben extraerse de la Constitución y de otras normas como las comprendidas en el derecho de las limitaciones de la competencia (antitrust y abuso de posición dominante).

La evolución que comentamos hace que entre en crisis la denominada «relación de competencia», hasta ese momento presupuesto de aplicación de la disciplina. En efecto, el nuevo cuadro de intereses y valores dentro del cual se va acomodando progresivamente la institución, y la remodelación del ilícito concurrencial en torno al abuso del derecho, han originado dicha 
crisis, pues ya no se exige para la aplicación de la normativa la relación entre empresarios competidores: lo que ahora se persigue es proteger los intereses de todos los participantes (es decir, también de los consumidores), así como también los objetivos políticos, económicos y sociales del sistema. Cabe apuntar que el abandono del concepto de «relación de competencia» se produce en los ordenamientos modernos con distinta intensidad y en algunos países expresamente por la vía de la reforma legislativa (Menéndez, 118 a 120).

\subsection{Competencia prohibida y competencia desleal}

Como bien dice $\mathrm{H}$. Baylos, la competencia ilícita implica el ejercicio de una actividad concurrencial de la que hay obligación de abstenerse; y dentro de esa competencia ilícita cabe distinguir dos modalidades, a saber: la competencia prohibida y la competencia desleal (Baylos, 309).

En la competencia prohibida, que puede tener su origen en la infracción a una ley o a un contrato, lo ilícito resulta ser el ejercicio mismo de la concurrencia, es decir, que determinado tipo de actividad económica no puede ser desarrollado por algunos sujetos, ya que tienen la obligación de abstenerse. Existe tal prohibición, por ejemplo, cuando por ley se crean monopolios estatales, cuando la administración otorga concesiones del más diverso tipo, cuando se imponen determinados requisitos para el ejercicio de una profesión. También en los casos de los derechos de la propiedad intelectual e industrial. En sentido opuesto cabe decir que en lo que no está prohibido expresamente, la competencia es lícita y permisible (Baylos, 309).

Pero la obligación de abstenerse puede también tener origen en un convenio, tenga éste el carácter de principal o de accesorio de otro, lo que es común en los de distribución o de licencia, en virtud de los cuales una de las partes debe abstenerse de efectuar competencia para garantizar el cumplimiento de la obligación principal. Por ejemplo, en el contrato de cesión de empresa normalmente se establece la obligación del cedente de abstenerse de ejercer la misma actividad económica que constituye el objeto de la empresa cedida, al menos en el habitual territorio bajo su influencia, con el objeto de que el trasmitente no distraiga la clientela adquirida -cuya cesión directa es imposible - y también para que no obstaculice la obtención de nueva clientela. En estos casos lo prohibido resulta ser el desarrollo de la 
actividad económica, aunque ella se realice con toda pulcritud y corrección (Baylos, 310).

En cambio, en la competencia desleal, que es la otra cara de la competencia prohibida, la actividad es en sí misma lícita y permisible, estando únicamente prohibido ejercerla por determinados medios reprobables. De ello se deduce un hecho de singular importancia y es que en la competencia desleal no se sanciona con la ilicitud el haber causado a otro un daño concurrencial — pues éste es lícito- sino el haberlo causado indebidamente. En la lucha por el triunfo del mejor, en ese campo de batalla que es el mercado, las armas lícitas son la calidad, el precio, la diversidad de prestaciones, la publicidad, que, aunque agresiva, no engañe, etc., pero no lo son aquellas que alteren la igualdad de oportunidades de los competidores, porque ello se transforma en un daño indebido del que hay que responder (Baylos, 311, 312).

\subsection{Relatividad del concepto de competencia desleal}

Según el Diccionario de la Real Academia Española (vigésima edición, 1984) desleal es el que obra sin lealtad, y leal es ser «fidedigno, verídico, legal y fiel, en el trato o en el desempeño de un oficio o cargo», que, para lo que nos interesa, es una actividad que consiste en ofrecer bienes o servicios en el mercado. Debe, pues, el oferente sujetarse a determinadas normas que denominaremos con Baylos de honorabilidad y honradez, frente a los competidores y los consumidores (Baylos, 313). Y, por cierto, también encuadrarse dentro de los parámetros dispuestos por el orden público económico.

Pero como es fácilmente apreciable, el concepto de deslealtad no puede ser absoluto ni haber tenido en todas las sociedades y en todo tiempo el mismo contenido o igual importancia. Por tanto, actuar deslealmente en el ámbito económico empresarial es hacerlo de modo contrario a lo que la costumbre social o la moral comercial acostumbra a admitir; de ello se deduce que por lo menos para determinadas actuaciones el juicio condenatorio variará según el lugar y el tiempo. Así, si bien el concepto de competencia desleal no deja de tener un fondo moral común, se trata de una noción relativa a la época, al país y al estamento social (Baylos, 314). 
Como es lógico, este fenómeno de la competencia ha sido y es especialmente sensible en su regulación jurídica a la evolución de factores políticos, ideológicos, económicos y tecnológicos; y, por tanto, aquella regulación, y la estimación de lo que es o no desleal, tiene forzosamente que ser distinta en una producción artesanal, que en una economía industrializada y de tráfico masificado donde la publicidad ya no es sólo informativa sino agresiva y hasta agobiante, características que frecuentemente se convierten en mérito en la vida mercantil (prólogo de Olivencia en: Font, 16). Por cierto que siempre han formado parte del contenido de la disciplina de la competencia desleal la maniobra fraudulenta o la conducta que implica engaño, pues siempre han sido universalmente reprobadas, pero sus manifestaciones más salientes asumen en el tiempo modalidades distintas (Baylos, 314).

\subsection{Definición}

Debe quedar claro, entonces, que cuando hablamos de competencia desleal nos estamos refiriendo a un tipo de actividad que persigue la atracción y captación de compradores - la formación, consolidación o incremento de la clientela- utilizando medios tortuosos que la conciencia social reprueba como contrarios a la moral comercial, según la costumbre y los usos, que permiten potenciar la empresa propia como debilitar a las rivales, y que es, además, contraria a los principios rectores de la actividad económica, incorporados muchas veces en la Constitución o en leyes reguladoras de dicha actividad.

\subsection{La técnica jurídica de represión}

Como hemos ya dicho, «la ilicitud de la competencia desleal puede derivar jurídicamente, bien de la aplicación del principio general que declara la responsabilidad por daño causado a otro, bien de la existencia de una ley especial represora» (Baylos, 314). En algunos ordenamientos, donde no existe un precepto legal que de modo específico defina y prohíba los actos de competencia desleal, se ha utilizado la vía de la responsabilidad extracontractual o aquiliana, y la jurisprudencia ha acogido los supuestos desleales en tal categoría. 


\subsubsection{Represión mediante la aplicación del principio de la res- ponsabilidad extracontractual}

El ejemplo típico de estos sistemas es el francés; la jurisprudencia ha sabido sancionar las actuaciones desleales con la condena a la cesación del acto y una indemnización por daños y perjuicios, considerando que competir de modo desleal es realizar un acto ilícito comprendido en el artículo $1382^{\circ}$ del Código Civil francés ${ }^{2}$. Es opinión muy extendida que la jurisprudencia francesa ha elaborado un concepto amplio y previsor de competencia desleal, de eficaz aplicación práctica a la cambiante realidad.

Ahora bien, la ilicitud de actuación desleal plantea el problema de la fundamentación jurídica de esa calificación. La doctrina y la jurisprudencia francesas la encuentran en la teoría del abuso del derecho, la que se extiende a los casos en que el derecho es ejercido de modo imprudente o negligente, sin motivo serio y legítimo. Pero como no es posible decir que el abuso del derecho requiere siempre la intención de causar un daño, se traslada a esta materia la idea - de tanta aceptación en el derecho público-de la desviación del poder, es decir, cuando el ejercicio del poder se aparta de su finalidad. Así, si bien todo competidor tiene el derecho de emplear en la actividad concurrencial sus medios, su iniciativa, debe hacerlo conforme al interés público, razón por la cual si se desvía de esa finalidad su actuación debe considerarse abusiva, es decir, no puede hacer uso de la libertad de competir de una manera excesiva ya que ello significa sobrepasar los hábitos y usos sociales. También, por cierto, numerosas resoluciones jurisprudenciales francesas sobre actuaciones desleales están basadas en la mala fe, en la utilización del fraude o en la intención de causar daño a otro (Baylos, 316).

En la construcción jurisprudencial francesa la competencia desleal es la infracción a un deber exigido por la propia naturaleza de las cosas, ya que competir significa participar en una licitación utilizando medios admitidos y honrados. Conviene aclarar que esa infracción a un deber - que Ascarelli denomina «deber moral de corrección» (Ascarelli, 157)- se configura en Francia como un ilícito civil y no penal, que puede dar lugar a una reparación económica del daño (Baylos, 316-317).

2 Equivalente al artículo $1969^{\circ}$ de nuestro Código Civil: «Aquel que por dolo o 


\subsubsection{Represión mediante ley especial}

\subsubsection{Cláusula general}

En un segundo conjunto de sistemas, mucho más numeroso que el anterior, la represión en la competencia se confía a la existencia de una ley especial cuyo paradigma ha sido la ley alemana del 7 de junio de 1909. Pero como la experiencia ha acreditado que no es posible ejemplarizar todos los supuestos de un modo estricto de acuerdo a la técnica de la tipicidad, estas leyes resumen su criterio valorativo de la ilicitud de las conductas que se tachan de desleales en una definición omnicomprensiva de todas las manifestaciones concretas de deslealtad, y que luego se complementa por una enumeración de actos que no pretende ser exhaustiva.

Debe quedar aclarado que es opinión unánime que para considerar a un acto como desleal, a los efectos de la ley, basta que incurra en la noción contenida en la cláusula general, sin que sea preciso que además figure tipificado en alguno de los supuestos que se enumeran, los que poseen fundamentalmente un valor ilustrativo y ejemplificador (Baylos, 317).

El artículo $1^{\circ}$ de la ley alemana de 1909 consigna la siguiente cláusula general: «El que en el tráfico mercantil realiza actos, con finalidad de competencia, que atentan contra las buenas costumbres, puede ser sometido a una reclamación de cesación y de reparación del daño». Lo que sirve de defensa frente a la competencia desleal — dice Fikenstscher, citado por Baylos - no es ninguna exigencia relativa a la lealtad misma considerada como un valor, sino al comportamiento acostumbrado, usual, socialmente admisible. Así, cualquier criterio de valor queda supeditado por su remisión a las costumbres honestas y honradas, es decir, a lo que vienen haciendo todos, con aprobación social, lo que obliga a los concurrentes a utilizar medidas conscientes y habituales, y no excepcionales y desacostumbradas, cuyo empleo colocaría a los demás competidores en una situación de desigualdad e inferioridad, contraria a la esencia misma de toda licitación, en la que no puede jamás admitirse ventaja de uno sobre otros (Baylos, 318).

En la extensión de esta técnica de la ley especial a muchos países, ha

culpa causa un daño a otro está obligado a indemnizarlo. El descargo por falta de dolo o culpa corresponde a su autor». 
jugado un importante papel la existencia de una definición de competencia desleal, con el valor de una cláusula general, en el artículo 10 bis del Convenio de la Unión de París, del que son parte la mayoría de los países - y entre ellos los más desarrollados- aunque no el Perú.

\subsubsection{Supuestos típicos}

Como es natural, cada ley incluye su propia lista de supuestos típicos o concretos de competencia desleal, pero generalmente todas coinciden en incluir aquellos supuestos que ocurren con mayor o menor intensidad en casi todos los mercados de las sociedades modernas. Sin perjuicio de ello, éste es un campo fértil para apreciar por qué la competencia desleal no es una institución de contenido homogéneo. Lo anterior ha dado lugar, como se comprenderá, a que la doctrina proponga un gran número de clasificaciones de esos actos, teniendo como criterio básico la finalidad del acto mismo.

Así, por ejemplo, para el francés $P$. Roubier los medios constitutivos de la competencia desleal pueden agruparse así: a) medios de confusión (consistentes en crear confusión entre distintivos propios y los de otro comerciante); b) medios de denigración (de la persona, del establecimiento o de los productos del competidor); c) medios de desorganización de una empresa rival (divulgación de secretos de fábrica, reclutamiento de empleados, etc); y d) medios de desorganización general del mercado (publicidad engañosa, etc.) (Baylos, 321, nota 175). Para Baylos, por su parte, un primer grupo está constituido por comportamientos en que la nota de antijuridicidad la da de modo esencial la apropiación indebida de valores ajenos, siendo el fraude el común denominador (empleo o imitación total o parcial de signos distintivos idénticos o semejantes a los de un competidor, por ejemplo); un segundo grupo está conformado por comportamientos que se caracterizan por implicar un ataque injusto a otro competidor, cuya característica común es la maquinación dañosa (ejemplo de ello lo tenemos en la denigración del competidor); y, por último, un tercer grupo está conformado por aquellos comportamientos que se definen como contrarios a la verdad en la comparecencia en el mercado y cuya actuación implica engaño, tales como las afirmaciones falsas o la publicidad basada en hechos inexactos (Baylos, 321 y ss.). Como se verá más adelante, en este artículo nosotros emplearemos una clasificación propuesta por Alberto Bercovitz, pues la consideramos más adecuada a nuestra ley. 


\subsection{Naturaleza y contenido de la acción de competencia desleal}

Como habrá ya podido apreciarse, la finalidad que persigue la acción contra la competencia desleal es eliminar el comportamiento desleal y hacer, en lo posible, que el mercado vuelva a su situación anterior; la finalidad es, pues, fundamentalmente restauradora - ya que lo que interesa es hacer cesar al acto desleal y suprimirlo para el futuro- y sólo en segundo término es reparadora. Si bien existen acciones penales expresamente establecidas para determinados tipos de deslealtad, es claro que la protección contra las infracciones desleales se encuadran preferentemente dentro del derecho civil. Ello es aceptado en el derecho comparado, que ha dividido esas acciones en dos grandes grupos, dependiendo de la existencia o no de culpabilidad en el agente productor del acto desleal. Dentro de este último se encuentran las acciones de cesación y remoción de los efectos causados por la conducta o acto desleal, en las que no será necesaria la constatación de la existencia de «culpa», bastando con que se dé un acto que objetivamente pueda considerarse como desleal. El segundo grupo comprende la indemnización de daños y perjuicios, la misma que procederá si se da el elemento subjetivo de la existencia de «culpabilidad» en el sujeto que origina el acto desleal, aun en el caso que se haya decretado la cesación del mismo y la remoción de sus efectos (Molina, 98, 99). Como veremos, en nuestro país existen en el ámbito penal algunas normas aplicables a esta disciplina; en lo que se refiere al ámbito civil, resulta obligatorio agotar previamente la vía administrativa, en la cual el afectado cuenta con varios tipos de acciones, pudiendo solicitar medidas cautelares diversas al momento de interponer la denuncia correspondiente, adquiriendo el INDECOPI, organismo estatal encargado de las decisiones, un rol protagónico, aunque no exclusivo, que no se repite en otras latitudes.

\section{El decreto ley 26122}

\subsection{Antecedentes}

La primera norma moderna que en el Perú trató sobre la represión a la competencia desleal fue la ley 13270 de 30 de noviembre de 1959 en sus artículos $99^{\circ}$ y $100^{\circ}$, en cuya redacción se aprecia la influencia del texto corres- 
pondiente de la Convención General Interamericana de Protección Marcaria y Comercial suscrita el 20 de febrero de 1929 en la ciudad de Washington. La ley 13270, vigente hasta 1970 , fue derogada por el decreto ley 18350 , ley general de Industrias (LGI), promulgado por el Gobierno Revolucionario de la Fuerza Armada, lo que ocasionó que durante cinco meses, hasta inicios de 1971, no existiera norma legal interna sobre esta materia, esto es, hasta la puesta en vigencia del decreto supremo $n^{\circ}$ 001-71-IC/DS, reglamentario del antes citado decreto ley 18350 . El contenido de este reglamento, en lo que se refiere a competencia desleal, fue prácticamente igual al de la ley 13270 .

Creemos que es útil recordar que el órgano administrativo encargado de solucionar conflictos en esta materia durante la vigencia de las normas citadas cambió en repetidas oportunidades: de la Dirección Industrial del antiguo Ministerio de Fomento y Obras Públicas, esa competencia pasó a la Dirección de Propiedad y Registro Industrial del Ministerio de Industria y Comercio, y de ésta al Instituto de Investigación Tecnológica Industrial y de Normas Técnicas (ITINTEC), quien a través de su División de Amparo contra la Competencia Desleal ha venido resolviendo durante los últimos años en forma centralizada los casos que se han presentado, hasta la reciente creación del Instituto Nacional de Defensa de la Competencia y de la Protección de la Propiedad Intelectual (INDECOPI), por decreto ley $25868 \mathrm{deI}$ 24 de noviembre de 1992.

El conjunto de leyes liberalizadoras de la actividad económica a que hemos hecho mención al inicio de este artículo, y la circunstancia de que las normas sobre competencia desleal - como las referentes a propiedad industrial- eran lo único que quedaba vigente del D.S. $\mathrm{n}^{\circ}$ 001-71-IC/DS, reglamentario de un decreto ley (18350) derogado en 1982 por la ley 23407 , hacían necesario un nuevo dispositivo legal en esta materia, que tuviera, además, la jerarquía de ley. Esta necesidad se acentuó con la puesta en vigencia de la ley general de Propiedad Industrial (LGPI), decreto ley 26017, pues entonces sólo los artículos $110^{\circ}$ y $111^{\circ}$ sobre competencia desleal del decreto supremo $n^{\circ}$ 001-71-IC/DS quedaban vigentes.

El decreto ley 26122, ley sobre Represión de la Competencia Desleal de fecha 29 de diciembre de 1992, fue publicado el 30 del mismo mes en el diario oficial El Peruano. Esta norma, si bien significa una indudable mejora sobre la legislación anterior, no es en nuestra opinión totalmente satisfac- 
toria. En su parte sustantiva está directamente «inspirada» en la ley 3/1991 española sobre la misma materia. Como es lógico, es reflejo de un modelo concurrencial distinto al nuestro, es decir, correspondiente a un país mucho más desarrollado en lo económico e integrante de la Comunidad Económica Europea, lo que se hace especialmente visible al momento de proponer estándares de enjuiciamiento así como casos típicos. Esa «inspiración» en la ley española obligará en el futuro a un estudio detenido para confrontar el contenido del decreto ley 26122 con nuestra realidad empresarial y con los valores que en materia económica tienen nuestros agentes en el mercado; en otras palabras, para conocer con mayor precisión cuáles son las normas de conducta que rigen el tráfico económico en nuestro país.

Podemos decir, simplificando, que en el Perú también se presentaron, pero con distinta intensidad y en otro contexto, tres de las razones que Molina (Molina, 253-254) señala como inexcusables para la promulgación de una ley de competencia desleal en España: la creciente demanda social de un marco jurídico cierto y eficaz que sea apto para dar cauce a la lucha en el mercado; la necesidad de homologar, en el plano internacional, nuestro ordenamiento jurídico en esta materia, más aún ante la creciente globalización de la economía y la liberalización de la misma, acompañada en nuestro caso de la necesidad de reinsertarnos en el mundo financiero internacional y otorgar garantías a los inversionistas; y, por último, la necesidad de adecuar las normas a lo que se señala en nuestra Constitución económica de 1979.

Por último, cabe decir que al interior del INDECOPI se ha formado la Comisión de Represión de la Competencia Desleal ${ }^{3}$, a la que se le encarga

${ }^{3}$ El INDECOPI realiza sus funciones, según el decreto ley 25868, a través de dos tipos de reparticiones: una que denomina Oficinas y que se encuentran a cargo de un jefe, funcionario que hace carrera, y otra denominada Comisiones, que cuentan con un secretario técnico y que están conformadas por destacados profesionales, en su mayoría abogados. El propósito al crear las Comisiones ha sido, aparentemente, instaurar una instancia adecuada para resolver asuntos que se consideran muy «técnicos» y reemplazar a los antiguos funcionarios del ITINTEC, considerados poco adecuados para esta nueva función. Cabe decir que el nivel de preparación de buena parte del personal que realizaba funciones técnicas en el ITINTEC era muy superior al de otras reparticiones públicas y también de probada honorabilidad. Este personal ha sido en su mayoría cesado. Queda por ver si en el futuro las Comisiones estarán 
resolver en primera instancia las denuncias que se presenten por los afectados por un acto o conducta desleal, resoluciones que podrán ser apeladas ante un tribunal ad hoc dentro del mismo INDECOPI, con lo que se agota la vía administrativa. Por cierto que también podrá pedirse la nulidad de las resoluciones que emita el tribunal ante la Corte Superior de Lima.

\section{2 Ámbito territorial}

El artículo $3^{\circ}$ del decreto ley 26122 instituye que éste es de aplicación a los actos de competencia desleal que se realizan en el territorio nacional, esto es, en el mercado peruano. Creemos que el concepto de mercado, más económico que jurídico, debe interpretarse como el ámbito natural en que los bienes o servicios son ofrecidos, en el que se intercambian, y que las conductas o actos desleales son aquellos que lo afectan con una cierta relevancia en lo económico. No debe considerársele, por tanto, como algo estático y únicamente horizontal - relación entre competidores- sino como algo dinámico en el que son también relevantes las relaciones entre los agentes situados en estadios diferentes del proceso económico; en otras palabras, donde no es necesario que se produzca siempre, como veremos, una relación de competencia.

Ahora bien, el artículo $3^{\circ}$ es también de aplicación a «las importaciones de los bienes al país», y esto puede entenderse como una interesante propuesta al problema que plantea la extraterritorialidad de las conductas desleales, como consecuencia quizás de la influencia que ha tenido una sentencia norteamericana (U.S. vs. Alcoa), en la que se estimó de aplicación el Acta Sherman a conductas o empresas extranjeras siempre que existiere el propósito de afectar el mercado estadounidense (Otamendi, 123). La interpretación del artículo $3^{\circ}$ en ese sentido, se encuentra ratificada por el reciente decreto supremo $n^{\circ} 075-93-E F$, en virtud del cual las personas que se consideren afectadas por importaciones presuntamente devaluadas podrán presentarse ante la Comisión de Represión de la Competencia Desleal. Este dispositivo constituye un antecedente interesante para otorgar protección a

a la altura de la misión que les ha sido encomendada y no den lugar a conflictos de interés, lo que enturbiaría la función del instituto y le haría perder legitimidad frente a la opinión pública. En nuestra opinión las Oficinas, más que las Comisiones, son el tipo de repartición que debería existir en el INDECOPI. 
las actividades económicas nacionales frente a prácticas desleales ocurridas en el extranjero y que se manifiestan al momento de efectuarse importaciones $^{4}$. De no interpretarse en la forma expuesta u otra similar, consideramos que la mención «en las importaciones de los bienes al país» sería tautológica y carente de sentido.

\subsection{Objeto de la protección}

La finalidad perseguida por el decreto ley 26122 se encuentra en su artículo $1^{\circ}$, cual es «evitar, desalentar y sancionar los actos contrarios a la libre competencia en actividades económicas». Como sabemos, la libre competencia es, dentro de una concepción liberal, necesaria para lograr eficiencia y distribución equitativa del ingreso, y es también, en nuestro caso, un valor incorporado constitucionalmente. Ello es además coherente con la extendida convicción de que las prácticas desleales, en lo económico, no contribuyen a que pueda desarrollarse a cabalidad esa libre competencia, razón por la que debe evitarse se produzcan, y adicionalmente desalentar a los agentes económicos a que las practiquen y las consideren usuales. Si no se logra ese objetivo, entonces será necesario sancionar a quienes cometen esos actos ilícitos.

Ahora bien, siendo el fin fundamental de esta normativa proteger el funcionamiento correcto del sistema competitivo, evitando distorsiones por actuaciones incorrectas, resulta necesario proteger a todas las partes que intervienen en el mercado, sean empresarios o consumidores, siendo lo relevante para la aplicación de las normas esa participación en el mercado y no el hecho de que los participantes puedan ser o no calificados como empresarios (Bercovitz, 5-6). Tomemos por ejemplo el caso de quien ha heredado una pieza de cristal y que al momento de ponerla a la venta lo hace engañando sobre su procedencia o calidad; si bien no se trata de un empresario, no cabe duda de que esa actuación estará sujeta a las normas sobre competencia desleal.

4 El decreto ley 26122, por mandato expreso de su artículo $3^{\circ}$, no es de aplicación a los casos de dumping, uno de los «clásicos» actos desleales, sancionado en dos dispositivos: la Decisión 283 de la Comisión del Acuerdo de Cartagena y el decreto supremo $n^{\circ} 133-91-E F$. 
Lo anterior se ve ratificado por el texto del artículo $2^{\circ}$, el que dispone que la ley será de aplicación a todo tipo de personas naturales o jurídicas, incluidas las asociaciones sin fines de lucro, así como los gremios, sin otro requisito que el de realizar actividades económicas en el mercado.

En síntesis, podemos decir de la ley peruana lo que se ha dicho con respecto a la ley española, esto es, que introduce «un cambio radical en la concepción tradicional del derecho de la competencia desleal... [pues].... convierte la disciplina de la deslealtad en instrumento de ordenación y control de las conductas del mercado, considera la institución de la competencia como el objeto directo de protección de la normativa y realiza una apertura de los intereses protegidos, dando cabida a los intereses de los consumidores y al interés público» (Molina, 259).

\subsection{Relación de competencia}

Como hemos visto antes (supra 1.1.3), la evolución de la disciplina hace que no se exija siempre una relación de competencia para que el acto se califique de desleal. Como veremos, ello incide en la legitimación activa para interponer las acciones por competencia desleal, ya que ella no se atribuye únicamente a los empresarios, a los competidores directos, sino también a los consumidores, e inclusive a organismos de la administración pública (Bercovitz, 6).

Debe a este respecto decirse que en el decreto ley 26122 existe una referencia que puede llevar a equívoco en esta materia; en efecto, en el encabezamiento del título primero se hace mención a la «relación de competencia" pero no así en el texto propio de la ley. Ello se debe, creemos, a una omisión, ya que en el proyecto - al cual tuvimos acceso- había un artículo en el que se decía con toda claridad que para su aplicación la ley no se supeditará a la existencia de una «relación de competencia». Consideramos que después de una lectura detenida de todo el articulado puede afirmarse que, en efecto, la ley peruana para su aplicación no exige siempre, es decir, en todos los casos, una «relación de competencia».

\subsection{Exigencia de daño}

El artículo $5^{\circ}$ del decreto ley 26122 expresa categóricamente que «no se re- 
querirá acreditar un daño efectivo o un comportamiento doloso" para calificar el acto como de competencia desleal, y que bastará que el perjuicio sea potencial e ilícito a los competidores, a los consumidores o al orden público, debiéndose entender este último, en nuestra opinión, como el orden público económico constitucionalizado.

El fin que persigue la normativa es reprimir la conducta incorrecta, y para ello no es requisito la mala fe del autor ni que la conducta haya causado un perjuicio. Esto, sin embargo, no puede llevarnos a desconocer que la mayoría de los actos de competencia desleal se realizan con mala fe subjetiva, y que esa mala fe y la producción cierta de un perjuicio son jurídicamente relevantes, resultando incluso imprescindibles para el ejercicio de determinadas acciones, como por ejemplo para solicitar una indemnización por daños y perjuicios, pero no son requisitos para que un acto sea calificado como desleal, o para pedir su cesación (Bercovitz, 6-8). Habrá, sin embargo, casos específicos en los que la ley exige que la mala fe sea un elemento determinante de la incorrección de la conducta prohibida y también para la cesación de la misma, como es el caso de la sustracción de secretos empresariales consignado en el artículo $15^{\circ}$ b) del decreto ley 26122 .

\subsection{Actos desleales graves y leves}

El párrafo segundo del artículo $5^{\circ}$ de la ley contiene una norma polémica; en él se dice que el acto o conducta desleal será grave cuando «se encuentre específicamente dirigido a alejar o sustraer ilícitamente la clientela de un competidor». No es fácil encontrar fundamento a esta afirmación, ya que en el proyecto de ley se decía «acto de competencia más grave», de lo que se deducía que todos los actos desleales eran graves, aunque algunos más que otros.

El sentido de la ley es ahora distinto, ya que únicamente serán considerados actos graves los que caigan bajo lo consignado en el segundo párrafo, y leves todos los demás. Y creemos que esta calificación deberá tenerla presente el juzgador al momento de escoger las sanciones solicitadas por el denunciante - que se mencionan en el artículo $22^{\circ}-o$ al determinar el monto de las multas a que se refiere el artículo $29^{\circ}$.

El párrafo segundo del artículo $5^{\circ}$ nos trae otra interrogante: ¿es posi- 
ble la existencia de un acto de competencia desleal que no se encuentre «específicamente» dirigido a alejar o sustraer la clientela de un competidor? Si bien es cierto que esa respuesta dependerá de lo que entendamos por alejar o sustraer la clientela ajena — se entiende que ilícitamente, pues no se trata aquí del daño concurrencial que, como ya hemos visto, es lícito-, en nuestra opinión todo acto desleal tiene como fin disminuir la clientela del rival o rivales, inclusive aquellos actos comprendidos en la categoría de los que miden el correcto funcionamiento del mercado, aunque dicho propósito no se manifieste siempre con igual claridad e intensidad.

Pero existe también «otra lectura» del párrafo en cuestion: para la ley peruana lo efectivamente grave son las conductas o actos destinados a buscar disminuir directamente la clientela del rival, como ocurre - por ejemplo- cuando se trata de explotar la reputación ajena en beneficio propio imitando signos distintivos. Es de esperar que en el futuro, principalmente por el Tribunal del INDECOPI, se nos ofrezca las pautas adecuadas para la interpretación de este artículo.

En nuestra opinión, sin embargo, el aspecto más relevante es otro: si bien en el modelo de nuestra ley_-adoptado de la ley española - basta que una actuación sea incorrecta y perjudique a cualquiera de los participantes en el mercado, por ejemplo a los consumidores, para que sea calificada de desleal, no precisándose ya una «relación de competencia»; según el párrafo segundo del artículo $5^{\circ}$ los actos desleales graves para nuestro legislador son aquellos en los que sí hay una relación de competencia, es decir, aquellos mediante los cuales un empresario - y sólo un empresario y no quien actúa esporádicamente en el mercado - trata de alejar o sustraerle la clientela a otro empresario. Se trata de «profesionales», que «tienen clientela»o aspiran a tenerla, que actúan como tales en el mercado, y no quienes desean simplemente obtener «un comprador», aunque lo hagan deslealmente.

Ahora bien, lo anterior no debe llevarnos a olvidar que si bien la gran mayoría de los actos desleales son contrarios a la buena fe comercial, su existencia es independiente de la calificación del acto como desleal y del perjuicio o no que produzca. Como ya hemos visto, la mala fe no es requisito para la calificación ni tampoco lo es el hecho de que se haya o no causado perjuicio. Nuestra ley dice otra cosa: que los actos que considera más graves en esta materia de la deslealtad son aquellos en los que existe una relación de competencia. De esta forma y a través de este artículo, de 
singularísima importancia, se ha matizado todo el contenido de la ley y no se ha adscrito en su totalidad al modelo que propone la ley española.

\subsection{Cláusula general prohibitiva}

Como hemos dicho antes (supra 1.5.2.1), es usual que en los sistemas de represión de la competencia desleal mediante una ley se incluya una cláusula general prohibitiva seguida de una enumeración de supuestos concretos de comportamientos sancionables. Este planteamiento, como lo pone de manifiesto la experiencia, es el más eficaz. La cláusula general establece la prohibición en unos términos que permiten incluir supuestos no específicamente previstos, sea por su carácter extraño o marginal, o bien por la evolución de las prácticas comerciales que da lugar a la aparición de nuevos comportamientos incorrectos. De lo que se deduce su necesidad, pues evita que la normativa quede obsoleta debido al desarrollo de nuevas prácticas desleales (Bercovitz, 6-7).

Uno de los aspectos más significativos, al momento de evaluar una cláusula general, es conocer cuáles son los criterios que han sido seleccionados para determinar la deslealtad de una conducta o de un acto. En el artículo $6^{\circ}$ de nuestra ley estos criterios son tres, a saber: a) la buena fe comercial; b) el normal desenvolvimiento de actividades económicas; y c) las normas de corrección que deben regir las mencionadas actividades.

La buena fe es un principio jurídico, no un precepto o una norma en sentido técnico, de profundo contenido ético, conceptuada «como la convicción de estar obrando conforme a las reglas jurídicas» (Molina, 263). La doctrina civilista acepta una distinción entre buena fe objetiva y buena fe subjetiva, siendo la primera una regla de conducta mientras que la segunda aparece como guía para la intención. Nos interesa fundamentalmente la buena fe objetiva, que no se basa en la voluntad de las partes sino en la adecuación de esa voluntad al principio que inspira y fundamenta el vínculo negocial. La buena fe comercial que se menciona en el artículo $6^{\circ}$ hace referencia a un determinado modo de actuar en las relaciones de mercado, conectándose directamente con la libertad de competencia y el abuso de dicha libertad; no se refiere a los sujetos de una relación jurídica, sino a los agentes de la libertad de competencia en el uso de tal libertad, los que se deben adecuar al interés de la economía en general (u orden público económico) 
así como al interés de todos los que participan en el mercado (Molina, 265 y 266).

En cuanto a los dos otros criterios, normal desenvolvimiento de actividades económicas y normas de corrección, es importante tener presente que el enjuiciamiento hay que hacerlo recurriendo al concepto de «competencia practicable, operativa o efectiva», concebida como aquella en la que el acceso al mercado está abierto, como aquella en que las alteraciones de la oferta y la demanda se traducen en los precios, como aquella en que la producción y la venta no se limitan artificialmente, como aquella en que la libertad de elección no se ve obstaculizada; en fin, como aquella en que la lucha concurrencial se desarrolle sobre las prestaciones más eficientes, por lo que la expulsión del mercado de algunos empresarios se produzca por la mayor eficiencia de las prestaciones de los competidores, leal y correctamente. Este concepto de competencia está implícito en nuestra Constitución económica de 1979.

\subsection{Supuestos concretos de competencia desleal}

Hemos dicho ya antes (supra 1.5.2.2) que es bastante difícil realizar una acabada clasificación de los supuestos concretos de actos desleales. A ello se suma la crítica que hace la doctrina española a su ley en el sentido de que resulta excesivo su afán tipificador, crítica que compartimos y que es aplicable al decreto ley 26122 , pues éste repite en casi su integridad la clasificación de la ley española, agregándole en ocasiones un matiz que la mejora y en otras suprimiendo injustificadamente unas palabras. Como también ya hemos dicho antes, nos acogemos para los propósitos de este artículo a la clasificación que hace Alberto Bercovitz (Bercovitz, 8) para la ley española.

\subsubsection{Actos o conductas consistentes en aprovecharse del esfuer- zo de otros participantes en el mercado}

Incluiremos bajo este título -en primer término- a los actos de confusión (artículo $8^{\circ}$ ), imitación (artículo $13^{\circ}$ ) y explotación de la reputación ajena (artículo $14^{\circ}$ ), por estar íntimamente conectados. Como bien lo ha puesto de manifiesto De la Cuesta, en la confusión suele haber imitación, y la imitación - en la gran mayoría de los casos - se realiza con la pretensión de 
confundir; además, mediante la confusión y la imitación hay un aprovechamiento o explotación de la reputación ajena (De la Cuesta, 35).

\subsubsection{Actos de confusión}

ARTÍCULO $8^{\circ}$.- Actos de confusion.- Se considera desleal toda conducta destinada a crear confusión con la actividad, las prestaciones, los productos o el establecimiento ajeno.

El riesgo de confusión a que se vean expuestos los consumidores respecto de la procedencia empresarial de la actividad, producto, establecimiento o prestación es suficiente para determinar la deslealtad de una práctica.

La confusión es un acto típico de competencia desleal, probablemente el más antiguo e importante, que aparece en prácticamente toda la legislación comparada.

El interés a la diferenciación en el mercado es el primer pilar del sistema de competencia, pues los empresarios deben ser premiados por su propio esfuerzo y no por el provecho ilícito que obtienen de otros; obviamente, el riesgo de confusión viola o ataca dicho interés. Por tanto, el que las actividades estén diferenciadas y sean distinguibles los productos, los servicios o los establecimientos interesa a los competidores y a los consumidores, reales o potenciales.

Cabe señalar, en primer término, que en la ley peruana no puede desestimarse la intencionalidad de quien provoca la confusión («conducta destinada a crear confusion»), lo que nos obliga a no considerarla solo de modo objetivo. En segundo lugar, que la ley no diștingue, ni tendría por qué hacerlo, en cuáles son los medios idóneos a ser empleados para crear confusión, ya que en principio su número es ilimitado.

Si bien el artículo $8^{\circ}$ de la ley no suministra el criterio jurídico del concepto de riesgo de confusión, la doctrina considera que ese riesgo «equivale a la amenaza de que potenciales clientes puedan sufrir un error sobre el origen de las prestaciones o sobre la identidad de los establecimientos» (De la Cuesta, 36). Por cierto que es para proteger el interés de la diferencia- 
ción entre empresas, establecimientos y productos que se han creado los derechos sobre los nombres comerciales y las marcas.

En la realidad coexisten el régimen de protección a los signos por sí mismos (contenido en la LGPI $n^{\circ} 26017$ ) y la disciplina de la competencia desleal. Las fronteras entre estas dos áreas no están siempre claramente trazadas, ni son inmutables. Bercovitz ha dicho que la protección de los derechos exclusivos de propiedad industrial y la protección contra la competencia desleal forman dos círculos concéntricos, estando en el más pequeño los derechos absolutos y en el más amplio la protección contra la competencia desleal; por tanto, el medio de protección más fuerte se encuentra en el terreno de los derechos exclusivos, mientras que el círculo más amplio pero menos sólido se da en los casos de competencia desleal, ya que en este último la protección depende de las circunstancias y de la forma en que actúe el agente desleal en el mercado. Sin perder de vista, pues, la necesaria flexibilidad que debe acompañar el análisis de la situación planteada, cabe decir que la diferencia se encuentra en que quien viola un derecho exclusivo de propiedad industrial está incurriendo en un acto ilícito por el solo hecho de utilizar, sin estar autorizado, un objeto protegido (ej., marca registrada); mientras que en los casos de competencia desleal no se viola ningún derecho absoluto, siendo ilícito e incorrecto un acto por circunstancias concretas (Bercovitz, 4).

Puede apreciarse que la disciplina de la competencia desleal cumple así una función integradora respecto de la propiedad industrial, pues el riesgo de confusión no se circunscribe a productos o servicios idénticos o similares como en las marcas, sino que puede ir más allá, al llevar al público a error al atribuir a una empresa los productos o las prestaciones de otra, error que puede incluso producirse en ausencia de una posible confusión entre signos (De la Cuesta, 37).

De la Cuesta menciona algunas reglas para hacer un juicio sobre el riesgo de confusión. En primer término, no es imperativo que la confusión se haya efectivamente producido, pues basta el riesgo o amenaza de que se produzca, según reza el párrafo segundo del artículo $8^{\circ}$. En segundo lugar, el elemento interpretativo esencial reside en la percepción que el consumidor medio tenga de la prestación de los respectivos competidores (Otamendi, 141), de su capacidad de diferenciación, con atención especial a la impresión general (Molina, 274). Así, por ejemplo, nada impide que un 
empresario use como signo diferenciador una marca no registrada pero que fue utilizada por un tercero con anterioridad, el que no se molestó en registrarla o en renovar el registro; si bien, entonces, resulta en principio lícito su uso por terceros, ese uso podría ser desleal en la medida en que pueda provocar confusión al consumidor (Otamendi, 141). En tercer término, debe tenerse presente para el juicio acerca de la confundibilidad la impresión general producida sobre el universo correspondiente al cual pertenece ese consumidor medio (De la Cuesta, 39-40).

Cabe hacer referencia, por último, a la gran importancia que tiene actualmente la publicidad en la vida mercantil, la misma que puede tomar asiento en múltiples supuestos tipificados de desleales. De entre ellos destacan los actos de confusión, pues la publicidad asentada en signos distintivos es lugar adecuado para cobijar la mayoría de los supuestos de generación de riesgo de confusión. A este respecto puede verse el artículo $4^{\circ}$ del decreto legislativo 691, sobre publicidad.

\title{
2.8.1.2 Imitación de iniciativas
}

\begin{abstract}
ARTÍCULO $4^{\circ}$.- No se considerará como acto de competencia desleal la imitación de prestaciones o iniciativas empresariales ajenas, salvo en lo que en esta Ley se dispone o en lo que lesione o infrinja un derecho de exclusiva reconocido por la ley.
\end{abstract}

Si bien este artículo reafirma el derecho constitucional a la libre iniciativa en el ámbito económico, a su vez ratificado en el decreto legislativo 757, constituye un acierto su inclusión en el decreto ley 26122, así como su ubicación en el título I. Creemos pues que es conveniente dejar sentado en un dispositivo legal como el que venimos comentando, y cuya materia es poco conocida en el medio profesional y judicial, que el libre acceso al mercado y la imitación de iniciativas empresariales es libre, esencial en un sistema de mercado, teniendo como únicos límites lo dispuesto en la propia ley y la lesión de un derecho de exclusiva reconocido por la ley, entre otros y fundamentalmente, los derechos intelectuales comprendidos en la legislación de derechos de autor y propiedad industrial, auténticos monopolios temporales que deben ser entendidos como excepciones al sistema general, y que logran su justificación en el fomento a la creación y en el beneficio social que de ello se deriva. 


\subsubsection{Actos de imitación}

ARTÍCULO 13.- Actos de imitación.- Se considera desleal la imitación sistemática de las prestaciones e iniciativas empresariales de un tercero cuando dicha estrategia se halle directamente encaminada a impedir u obstaculizar su afirmación en el mercado y exceda de lo que, según las características, pueda reputarse como una respuesta natural a aquél.

Debemos decir que dentro de este artículo está comprendida únicamente la imitación sistemática, conocida también como competencia parasitaria, caracterizada por ser repetitiva, metódica e insistente en su propósito. La imitación eventual, esporádica, caerá bajo otros supuestos, tales como los de los artículos $8^{\circ}$ o $14^{\circ}$. Conviene precisar que la imitación sistemática debe exceder a lo que se considera como una respuesta natural del mercado, puesto que no cabe impedir que los competidores oferten a su clientela, por ejemplo, bienes o servicios en una forma tal que responda al gusto del día o a la moda.

Así, si bien muchas iniciativas de la competencia pueden, aisladamente consideradas, ser lícitamente imitadas, la imitación sistemática de su conjunto supone un aprovechamiento del esfuerzo ajeno, pues el imitador no ha invertido para ser más eficiente que los competidores. Se trata de una competencia de obstrucción, no fundada en la calidad o en el precio, sino destinada a eliminar al competidor, a trabar el funcionamiento de su empresa, no teniendo importancia el relieve o la originalidad de lo que se imita. Parecería - dice De la Cuesta- que una tal imitación habría de obedecer a un plan único, pero también puede responder a decisiones sucesivas, típicamente parasitarias (De la Cuesta, 46).

Aquí nos encontramos también frente a un caso en el que parece imposible no atender a elementos subjetivos para la determinación de la imitación que resulta desleal, ya que es difícil, sino imposible, imaginar actos o conductas «sistemáticas» que no tienen la expresa intención de causar daño. Puede decirse que en el acto mismo de imitación hay una voluntariedad, puesto que, por definición, el plagiario tiene a la vista el modelo a imitar (De la Cuesta, 44).

Ahora bien, en estos actos de imitación a que se refiere el artículo $13^{\circ}$ 
la deslealtad no proviene del riesgo de confusión - como en la imitación servil - sino del propósito de impedir la afirmación en el mercado de un competidor, es decir, obstaculizarlo de manera tal que no pueda crearse una reputación fruto de su esfuerzo (De la Cuesta, 46).

\subsubsection{Explotación de la reputación ajena}

ARTÍCULO $14^{\circ}$.- Explotación de la reputación ajena.- Se considera desleal el aprovechamiento indebido, en beneficio propio o ajeno, de las ventajas de la reputación industrial, comercial o profesional adquirida por otro en el mercado.

En particular, se reputa desleal el empleo o imitación de signos distintivos ajenos, así como el empleo de etiquetas, envases, recipientes $u$ otros medios de identificación que en el mercado se asocien a un tercero.

Ha dicho correctamente De la Cuesta que la «explotación de la reputación ajena» podría servir de título para todos los supuestos de confusión e imitación, pues en todos estos casos se da el aprovechamiento indebido de la reputación y esfuerzo ajenos, llegando a tener hasta el carácter de una pequeña cláusula general (De la Cuesta, 47).

En primer término, hay que señalar la estrecha vinculación del artículo $14^{\circ}$ con el $13^{\circ}$, referente a actos de imitación, porque en el segundo párrafo del artículo $14^{\circ}$ también se habla de imitación, pero en este caso específicamente de signos distintivos, envases u otros medios de identificación. En el artículo $14^{\circ}$, a diferencia del $13^{\circ}$ antes visto, no se exige tal imitación sistemática, bastando por contraste la eventual o puntual, referida a signos distintivos.

En segundo término, cabe anotar que si bien el artículo $10^{\circ}$ de nuestra ley no utiliza el término «imitación», se refiere al empleo no autorizado -cuya distinción con «imitación» nunca será, creemos, pacífica- de otros signos distintivos, como las denominaciones de origen, aun cuando se acompañen expresiones tales como «tipo», «modelo», etc. Más adelante veremos que se trata de un acto desleal contrario al funcionamiento correcto del mercado. 
En tercer término, conviene dejar apuntado que las formas de explotación de la reputación ajena podrán dar lugar a la confusión consignada en el artículo $8^{\circ}$ o al engaño tratado en el artículo $9^{\circ}$ de la ley.

En cuarto lugar, el aprovechamiento a que se refiere este artículo $14^{\circ}$ debe ser «indebido»; es lógico que así sea, pues la reputación industrial no puede considerarse como una propiedad excluyente de su titular, ya que en muchos casos los terceros pueden hacer mención o uso de ella dentro de las normas de corrección generalmente aceptadas. Así, por ejemplo, la Decisión 313 , en sus artículos $96^{\circ}$ y $97^{\circ}$ y la LGPI en su artículo $113^{\circ}$ permiten -y ello no es por tanto desleal- el uso de marcas de propiedad de terceros en estos casos en los que resulta inevitable para distinguir la propia actividad económica (recambio, repuestos, etc.). Lo consignado en el segundo párrafo del artículo $14^{\circ}$ refuerza la protección a los signos distintivos de las empresas contemplada en la Decisión 313 y en la LGPI.

En quinto y último lugar queremos enfatizar que en la mayoría de los casos subsumibles en este artículo $14^{\circ}$ estará presente - como en muchos otros desleales- el elemento publicitario (ver, en especial, el artículo $7^{\circ} \mathrm{del}$ decreto legislativo 691).

\subsubsection{Actos de comparación}

ARTíCULO $12^{\circ}$.- Actos de comparación.- Se considera desleal la comparación de la actividad, los productos, las prestaciones o el establecimiento propios o ajenos con los de un tercero cuando aquella se sustente en afirmaciones falsas o no comprobables.

La comparación no deberá crear confusión, ser engañosa ni denigrante a tenor de lo dispuesto en los artículos $9^{\circ}, 10^{\circ}$ y $11^{\circ} \mathrm{de}$ la presente Ley.

El supuesto de deslealtad de este artículo está referido, en su manifestación mayoritaria, si es que no única, a la publicidad comparativa. Como en muchos otros casos de actos desleales, pueden ser también de aplicación las normas sobre publicidad contenidas en el decreto legislativo 691. Ello obligará a conocer cuál será el estatuto jurídico más conveniente de aplicar. 
Dada su vinculación con el supuesto que venimos tratando, a continuación transcribimos el artículo $8^{\circ}$ del citado decreto legislativo 691.

DECRETO LEGISLATIVO 691: ARTÍCULO $8^{\circ}$.- Es lícito hacer comparaciones expresas de productos, incluyendo lo relativo a precios, si la comparación no denigra a los competidores ni confunde a los consumidores. Toda comparación debe ser específica, veraz y objetiva, y debe dar una apreciación de conjunto de los principales aspectos de los productos comparados.

Cabe decir que el artículo $10^{\circ}$ de la ley española, del que se tomó el artículo $12^{\circ}$ citado, se refiere a «comparación pública», habiéndose eliminado esta mención en la ley peruana. No creemos, sin embargo, que la deslealtad pueda producirse en un «ámbito privado», si éste lo entendemos como ajeno a las actividades económicas en el mercado, que son el supuesto esencial tanto del decreto ley 26122 como del decreto legislativo 691.

Si bien es cierto que en todo anuncio comercial subyace la vocación comparativa, esto es, la búsqueda de una confrontación con los bienes o servicios de los competidores, sólo algunos anuncios pueden definirse como manifiestamente comparativos, porque en ellos el mensaje apunta primordialmente a la confrontación.

Es fácil de constatar en nuestro medio, más aún ahora que se ha producido la apertura y desregulación de las actividades económicas, la cada vez más frecuente publicidad comparativa, debido — sin duda - a que ya no se encuentra proscrita y a una mayor agresividad en el mundo de los negocios. Esta mayor agresividad no debe confundirse con la denigración, figura cercana pero distinta de la publicidad comparativa, y quizás más propia de otras épocas, pues pone de relieve un proceder empresarial que podríamos denominar arcaico frente al mayor grado de refinamiento de la primera (Lema, 66).

Como se sabe, no ha sido siempre aceptada la publicidad comparativa; es más, en algunos países continúa prohibida, pues se considera que atenta contra el derecho del titular de una marca y contra el good will de la empresa correspondiente. La admisibilidad de la publicidad comparativa es, por tanto, un tema polémico, ya que pone en cuestión nociones tan importantes como la libertad de expresión, el derecho que tienen los consumidores a ser 
informados, la libertad de competencia y el derecho de exclusiva sobre un signo distintivo.

Durante los últimos años han venido triunfando los argumentos a favor de la publicidad comparativa; sea porque redundan en favor de la actividad económica, de los empresarios o de los consumidores. Se ha dicho, así, que promueve el incremento en la calidad y la innovación de los productos, que favorece la reducción en los precios y que contribuye a que la competencia retorne a su cauce normal; también, que con ella los empresarios están en situación de difundir más claramente las características de sus productos y permitir que ingresen más rápidamente al mercado; o, finalmente, que los consumidores podrán hacer una más adecuada decisión de compra.

Puede decirse que en el Perú quedó resuelta la polémica sobre la licitud de la publicidad comparativa con la promulgación del decreto supremo $\mathrm{n}^{\circ}$ 034-ICTI-IND del 11 de setiembre de 1990, ya derogado, que eliminó la publicidad comparativa de la lista de actos desleales (Diez Canseco, 19). Posteriormente, tanto por el artículo $8^{\circ}$ del decreto legislativo 691 sobre publicidad, como posteriormente por el decreto ley 26122 , ley sobre Represión de la Competencia Desleal, ha quedado definitivamente aceptada. Pero ello no significa, por cierto, que cualquier tipo de comparación en materia publicitaria se considere lícito, pues es necesario que cumpla con determinados requisitos que la doctrina, la jurisprudencia de países más avanzados y nuestra ley ponen de manifiesto.

La publicidad comparativa debe ser, sobre cualquier otra consideración, leal, veraz y objetiva; no debe confundir ni engañar a los consumidores, ni denigrar a los competidores. Y en cuanto a requisitos específicos que se le exigen, debe hacer referencia de los principales aspectos de los productos o servicios comparados, a datos específicos y comprobables.

Como ya hemos tenido antes oportunidad de comentar, el requisito de lealtad es difícil de determinar, pues no siempre se consideran como buenas a las mismas costumbres o usos comerciales; sin embargo, puede afirmarse que quien denigra a un competidor o a sus productos y servicios, esto es, quien difunde manifestaciones que dañan su crédito y reputación, no actúa lealmente.

La publicidad comparativa debe ser también veraz, es decir, no conte- 
ner alegaciones falsas, sea por omisión, ambigüedad, etc.; por tanto, debe ser informativa. Por cierto que no es fácil determinar siempre el engaño o la falsedad en un anuncio publicitario, pues las manifestaciones publicitarias no suelen ser inequivocamente falsas. El artículo $8^{\circ}$ del decreto legislativo 691 , al consignar la necesidad de «una apreciación de conjunto de los principales aspectos» en la publicidad comparativa, se está refiriendo a la obligación del anunciante de no silenciar datos importantes.

De otro lado, los datos a que hace referencia la publicidad comparativa deben ser esenciales y comprobables, estar compuestos de datos concretos y no accidentales, relevantes al producto o servicio, vinculados significativamente al valor o la utilidad ; en otros términos, deben tratarse de extremos análogos y mensurables. La comparación no se puede basar en la creencia u opinión del anunciante, sino en la certeza de la ocurrencia, evaluación que debería ser siempre llevada a cabo por una organización seria e imparcial, siguiendo métodos que permitan coherentemente apreciar las diferencias que se pretenden resaltar.

Estos son, en resumen, los requisitos generales y específicos aceptados por la doctrina, e incorporados a la legislación peruana; por lo tanto, deben tenerse presentes al momento de interpretar un anuncio publicitario en el que se hagan comparaciones, para saber así de su licitud o ilicitud.

Conviene decir que la normativa sobre publicidad no coincide en todo con la referente a la competencia desleal. Así, en la ley de publicidad se admite la comparación únicamente de productos y servicios, mientras que en la de competencia desleal es posible hacerlo, además, de las actividades, prestaciones y establecimientos. Pero ambas normativas coinciden, por otro lado, en que es posible la comparación no sólo de productos, servicios, etc., propios con los de un tercero, sino también hacerla entre los de terceros.

El segundo párrafo del artículo $12^{\circ}$ bajo comentario es similar al segundo del artículo $10^{\circ}$ de la ley española, del que su doctrina ha dicho que es superfluo (Otamendi, 154; Molina, 283; Lema, 75), opiniones con las que coincidimos por los mismos motivos, es decir, porque la comparación que contravenga lo establecido en los artículos $8^{\circ}, 9^{\circ}$ y $11^{\circ}$ de nuestra ley -y no como dice $\left\langle 9^{\circ}, 10^{\circ}\right.$ y $11^{\circ} \gg$ - no es comparación desleal sino acto de confusión (artículo $8^{\circ}$ ), de engaño (artículo $9^{\circ}$ ) o acto de denigración (artículo 
$11^{\circ}$ ), pudiendo por tanto prohibirle por la vía de la norma que expresamente trata cada caso.

\title{
2.8.1.6 Copia no autorizada
}

\begin{abstract}
ARTÍCULO $19^{\circ}$ - - Copia o reproducción no autorizada. - Se considera desleal la fabricación, la importación y la venta de productos que son copia o reproducción no autorizada de bienes de terceros protegidos por la legislación de Propiedad Industrial o de Derechos de Autor.
\end{abstract}

Éste es un acto desleal típico que no encontramos registrado en la legislación comparada; su origen se encuentra en el decreto supremo ${ }^{\circ} 009 \mathrm{~A}-83$ ITIIND, del 18 de marzo de 1983, que fuera dictado ante el justificado clamor frente a una creciente y extendida piratería - que no ha cesado- vinculada principal, pero no únicamente, a marcas notorias de prendas de vestir, cosméticos, productos medicinales, sobre todo aptos para la automedicación, videos del más diverso orden, cintas musicales, etc. Si bien éste no es un problema nacional, sino mundial, no cabe duda de que el extendido comercio informal que nos agobia ha sido y es vía propicia para el desarrollo de actividades ilícitas que han causado y causan profundo malestar en los titulares de derechos intelectuales debidamente protegidos por la legislación de propiedad industrial (Decisión 313, decreto ley 26017) o por la de derechos de autor (ley 13714). La falta de represión oportuna a las actividades de ese tipo - tendencia que no ha sido aún revertida por el novísimo INDECOPI- y la carencia de decisión política de parte de las autoridades municipales y nacionales son, sin duda, factores a considerar.

Ahora bien, como ya hemos dicho, las leyes citadas que protegen a los derechos intelectuales contienen sus propias vías para hacerlos valer frente a la infracción de terceros, lo que constituye el núcleo de protección más fuerte, cumpliendo las normas sobre competencia desleal una función de reforzamiento a las primeras, aspirando a constituirse en un medio eficaz aunque complementario para su protección. 


\subsubsection{Violación de secretos}

ARTÍCULO $15^{\circ}$.- Violación de secretos.- Se considera desleal:

a) La divulgación o explotación, sin autorización de su titular, de los conocimientos, informaciones, ideas, procedimientos técnicos o de cualquier otra índole, de propiedad de éste, y a los que un tercero haya tenido acceso legítimamente, pero con deber de reserva, o ilegítimamente, como resultado de alguna de las conductas previstas en el inciso siguiente o en el artículo $16^{\circ}$.

b) La adquisición de secretos por medio de espionaje o procedimiento análogo.

La persecución del infractor incurso en las violaciones de secretos señalados en los incisos anteriores se efectuará independientemente de la realización por éste de actividades comerciales o de su participación en el tráfico económico».

2.8.1.7.1 Antes de entrar a ver aquellos actos o conductas que constituyen ataques directos a otras empresas participantes en el mercado -el segundo grupo de supuestos escogido para la clasificación-, es necesario decir que en lo que se refiere a la «violación de secretos», supuesto tradicional en esta disciplina incorporado en el artículo $15^{\circ}$ de nuestra ley, la doctrina española (Bercovitz, 8) considera que la sustracción y explotación constituyen típicos actos tendientes al aprovechamiento del esfuerzo de otros participantes - primer grupo - mientras que la divulgación de secretos ajenos se ubica dentro del segundo grupo ya citado. Si bien nosotros coincidimos con esta apreciación, hemos decidido tratar este supuesto desleal dentro del primer grupo, es decir, dentro de los actos y conductas consistentes en el aprovechamiento del esfuerzo de otros participantes en el mercado, pues creemos que el mayor número de violaciones de secretos en nuestro medio cae bajo los supuestos de sustracción y explotación, realizados por quienes se encuentran en una situación de dependencia laboral o bajo contrato de servicios profesionales, siendo más bien excepcional la divulgación de secretos empresariales ajenos.

2.8.1.7.2 En nuestro ordenamiento jurídico la protección de los secretos se encuentra regulada, además de por el referente a competencia desleal que 
venimos tratando, en otros tipos de normas: principalmente en las de carácter penal (artículos $161^{\circ}$ y ss. y $240^{\circ}$ del Código Penal), y en las de carácter laboral (ley 24514 y decreto legislativo 728 ).

2.8.1.7.3 Puede considerarse secreto a aquel conocimiento que está reservado y oculto, cuyo poseedor -más allá de si es valioso o verdadero- tiene interés en mantenerlo en tal estado. Lo que disfruta de protección jurídica es su posible utilización ilegal. El ámbito material sobre el que puede versar el secreto es muy amplio (ver, por todos, Gómez Segade), pues abarca tanto los tradicionales secretos de fábrica o de producción (que son los comprendidos en el área de la propiedad industrial, ver decreto ley 26017 , artículos $81^{\circ}$ y siguientes) como cualquier otro, se trate de ideas, informaciones, procedimientos técnicos, etc. Ahora bien, los secretos que le interesan al decreto ley 26122 son los secretos empresariales, es decir, aquellos que pueden tener carácter tecnológico, comercial o financiero, siendo su concepto más amplio que el de secretos de producción.

2.8.1.7.4 La finalidad de esta prohibición de violar secretos empresariales es proteger la posición adquirida por un competidor a base de su propio esfuerzo. Debe tenerse presente que el secreto es un bien inmaterial frágil, pues su revelación lo destruye y le hace perder su capacidad competitiva, lesionando así a su titular. Cuando la ley, en el párrafo último del artículo $15^{\circ}$, dispone que no es indispensable que el infractor participe en el tráfico económico y, por lo tanto, que tenga una relación de competencia con el titular del secreto, está reconociendo, correctamente, una situación que puede darse en la realidad, esto es, aquella en la que la apropiación del secreto, como bien de carácter patrimonial que es, presenta interés no sólo para quien es activo en el mercado sino también para aquellos que sin participar pueden obtener un provecho, por ejemplo, revelándolo a un competidor a cambio de un pago.

2.8.1.7.5 Nos parece adecuado que la ley peruana no haya tomado de la española la referencia en el sentido de que quien viole un secreto debe tener ánimo de lucro o la intención de perjudicar, pues no creemos que exista motivo para condicionar la calificación de deslealtad a que se dé ese ánimo o intención. Lo que sí creeemos preciso es que el mantenimiento del secreto 
otorgue una ventaja competitiva, ya que nos movemos en el ámbito de los secretos empresariales; y desde esta perspectiva tiene que ser valioso, al menos para el empresario o la empresa que lo posea como tal. La violación, por ejemplo, de secretos de Estado, da lugar a una sanción que cae en otro ámbito y bajo distinta normativa.

2.8.1.7.6 Ingresando al análisis propiamente dicho de los artículos $15^{\circ}$ a) y $16^{\circ} \mathrm{b}$ ), cabe decir que en el inciso a) del primero se consignan dos situaciones objetivamente distintas: por un lado la divulgación y por otro la explotación; pero ambas situaciones coinciden en el aspecto subjetivo: el agente ha tenido que tener acceso al secreto, sea: i) legítimamente, pero con deber de reserva; y ii) cuando ilegítimamente se induce a la infracción contractual para que se produzca la difusión o explotación de un secreto empresarial. El tercer acto de competencia desleal sancionado es la adquisición de secretos empresariales por medio de espionaje o procedimiento análogo (artículo $\left.15^{\circ} \mathrm{b}\right)$ ).

Tanto la divulgación como la explotación se realizan sin autorización del titular. La divulgación debe entenderse como la comunicación a otro, y no en el sentido de que el secreto sea elevado a conocimiento de la generalidad, tal como se interpreta - por ejemplo- cuando ha vencido el plazo de una patente de invención y pasa a «dominio público» (Galán, 97). Si bien la ley no exige que el destinatario utilice el secreto, tiene por cierto que estar en condiciones de hacerlo, aunque no necesariamente de explotarlo, desarrollarlo o mejorarlo. La deslealtad se consuma por el hecho de la comunicación, pues, como hemos ya dicho, la ley está destinada en alguna medida a proteger el derecho del titular sobre «su» bien inmaterial.

De otro lado, cabe decir que divulgación y explotación pueden superponerse, de modo que en algunos supuestos la divulgación o comunicación constituirá una modalidad de la explotación (Galán, 98).

El supuesto más habitual es aquel de aquellos que han accedido al secreto legítimamente pero con deber de reserva: es el caso de los empleados, directivos y administradores. La obligación de guardar reserva durante la vigencia de la relación laboral viene dada en nuestra ley, pero no conocemos en el Perú norma que trate de esta situación después de la terminación del vínculo, quedando sujeto a lo que las partes pueden directamente acordar, 
aunque habrá supuestos en los que para el futuro trabajo profesional del exempleado sea indispensable hacer uso de los secretos. Este tema está obviamente abierto al estudio y al debate jurídico. Es usual que se considere circunstancia agravante la violación hecha por los directivos y por aquellos que gozan de cargos de confianza. Así, por ejemplo, lo dispone el artículo $87^{\circ}$ de la LGPI para el caso de revelación de secretos de producción.

Otro de los supuestos de acceso ilegítimo es aquel en el que éste se alcanza través del espionaje u otro procedimiento analogo (artículo $15^{\circ} \mathrm{b}$ )). En este caso resulta pertinente la referencia a los artículos $157^{\circ}, 161^{\circ}$ y $162^{\circ}$ del Código Penal (Peña Cabrera, I, 497, 525, 536). El espionaje es siempre deliberado, lo que excluye el conocimiento accidental, fortuito, que es consecuencia más bien de la torpeza del titular del secreto o sus colaboradores, y los métodos a emplear pueden ser variadísimos (Otamendi, 178). El sujeto agente de esta conducta desleal (divulgar o explotar) es no sólo el espía o el inductor a la infracción contractual (artículo $16^{\circ} \mathrm{b}$ )), sino también aquél en cuyo interés se realizó el espionaje o la inducción a la infracción contractual.

Cabe, por último, hacer una referencia al inciso b) del artículo $16^{\circ}$ que veremos en el apartado siguiente. Uno de los supuestos desleales de la inducción a la infracción contractual es aquel que tiene por objeto la difusión o explotación del secreto empresarial, y ello es así porque si bien incitar a la terminación regular de un contrato «es lo que pretende cualquier vendedor que intenta que el cliente del competidor pase a ser su cliente» (Otamendi, 180-181), dicha incitación no se permite en el anotado supuesto porque el agente pretende aprovecharse del esfuerzo de otro participante en el mercado usando métodos desleales. La interpretación de este apartado debe ser, en todo caso, restrictiva, por la razón antes anotada.

\subsubsection{Actos o conductas que constituyen ataques directos a otras empresas participantes en el mercado}

\subsubsection{Inducción a la infracción contractual}

ARTÍCULO $16^{\circ}$.- Inducción a la infracción contractual.- Se considera desleal:

a) La interferencia por un tercero en la relación contractual que 
un competidor mantiene con sus trabajadores, proveedores, clientes y demás obligados, y que tenga como propósito inducir a éstos a infringir las obligaciones que han contraído.

A tenor de lo dispuesto en el párrafo precedente, no será necesario que la infracción se refiera a la integridad de las obligaciones contraídas mediante el contrato, sino que bastará que se vincule con algún aspecto básico del mismo.

Del mismo modo, para que se verifique la deslealtad, no será necesario que el tercero que interfiera se subrogue en la relación contractual que mantenía su competidor con quien infrinja sus obligaciones contractuales.

b) La inducción a la terminación regular de un contrato o el aprovechamiento en beneficio propio o de un tercero de una infracción contractual ajena sólo se reputará desleal cuando, siendo conocida, tenga por objeto la difusión o explotación de un secreto empresarial o vaya acompañada de circunstancias tales como el engaño, la intención de eliminar a un competidor del mercado u otras análogas.

Con este artículo se incorpora una clara pauta de conducta competitiva con cargo a quienes son competidores entre sí, en el sentido de que no es aceptable que unos y otros induzcan a sus respectivos clientes, trabajadores, proveedores, etc., a infringir los contratos que mantienen recíprocamente en vigor.

En primer término hay que decir que la deslealtad ocurre si la infracción contractual se produce como resultado de la actividad inductiva, ya que si la infracción no tiene lugar la actividad realizada no puede calificarse de desleal; en otras palabras, no cabe aquí penalizar la tentativa, sino la obtención efectiva de una ventaja. Así, por ejemplo, una atenta lectura del inciso b) del artículo $16^{\circ}$ nos lleva a concluir que la mera intención de violar un secreto no se considera legalmente como desleal (Illescas, 109).

Creemos que hace muy bien la ley peruana al hablar de obligaciones y no de deberes como lo hace la ley española, por la connotación que tiene el término obligaciones, como de índole menor, meras cargas. Se trata, por cierto, de obligaciones contractuales principales, o de algún aspecto básico de la mismas, como dice el segundo párrafo del inciso a) del artículo $16^{\circ}$. 
Por tanto, la infracción inducida de prestaciones contractuales secundarias o accesorias no puede ser calificada como desleal si la prestación principal ha sido satisfecha (Illescas, 110).

En cuanto a los elementos subjetivos, tenemos, en primer lugar, al inductor de la infracción, que ha de encontrarse en una relación de competencia con el perjudicado, no teniendo que subrogarse en la relación contractual que mantiene el tercero con el perjudicado, según lo señala expresamente la ley; en segundo término, terceros vinculados contractualmente con el competidor perjudicado, los que han de incumplir las obligaciones principales que han pactado; y, por último, el perjudicado, que se encuentra en una doble relación con los anteriores: de competencia con el inductor, y contractual con los terceros que cometen la infracción. De lo anterior se colige que quienes se limitan a incumplir un contrato no contraen responsabilidad alguna en los términos del decreto ley 26122 (Illescas, 110-111), aunque sí respecto a las normas pertinentes del Código Civil y de otros preceptos aplicables.

Como se puede imaginar, la casuística que puede tener cabida en este supuesto desleal es amplísima.

\subsubsection{Actos de denigración}

ARTÍCULO $11^{\circ}$.- Actos de denigración. - Se considera desleal la propagación de noticias o la realización o difusión de manifestaciones sobre la actividad, el producto, las prestaciones, el establecimiento o las relaciones mercantiles de un tercero o sus gestores, que puedan menoscabar su crédito en el mercado a no ser que sean exactas, verdaderas y pertinentes.

Califican dentro de lo dispuesto en el párrafo anterior, entre otras, las manifestaciones que refieren a la nacionalidad, las creencias o ideología, la intimidad, la vida privada o cualesquiera otras circunstancias estrictamente personales del afectado.

Como diariamente podemos constatar, en el mundo de los negocios es usual que los empresarios revaloricen sus propias prestaciones, muchas veces exagerando sus cualidades o méritos, así como restándoselos a los de la competencia. Esta alusión a la actividad, al producto o al establecimiento 
del rival se efectúa casi siempre a través de la publicidad. En ocasiones será comparativa, lícita, pero en otras oportunidades no, encontrándonos ante un supuesto de denigración publicitaria. Por regla general en esta última sólo se alude a los productos ajenos (mientras que en la publicidad comparativa se alude a los productos ajenos y a los propios) (Lema, 65). Es, por tanto, de interés comentar este artículo, teniendo presente -en especial- lo dispuesto en los artículos $3^{\circ}$ y $7^{\circ}$ del decreto legislativo 691 sobre publicidad.

Los actos de denigración están destinados a ocasionar el descrédito de los competidores, más allá de si efectivamente lo logren o no. La diferencia fundamental que puede encontrarse con la legislación penal en lo que se refiere a los delitos contra el honor, en especial injuria, calumnia y difamación (artículos $130^{\circ}$ y siguientes del Código Penal), se encuentra en que la normativa sobre la competencia desleal está referida «al mercado», a que la diatriba contra los productos o servicios tiene por objeto el desprestigio del competidor en cuanto empresario y frente al público de los consumidores; por tanto, no todo acto injurioso o calumnioso puede calificarse como denigratorio, por lo menos en el sentido de la disciplina que reprime la competencia desleal.

La denigración es una agresión injustificada, que puede ser expresamente formulada o manifestarse por otro medio, y si bien será generalmente hecha en público (propagación y difusión son términos empleados por el artículo $11^{\circ}$ ) podrá bastar que la exteriorización llegue a un solo consumidor para que constituya competencia desleal (Molina, 281-282; Otamendi, 151).

No cabe duda de que será más frecuente que la denigración caiga sobre los productos (calidad, precio, etc.), o sobre la empresa rival (seriedad, etc.), que sobre los empresarios o gestores de las sociedades mercantiles; y cuando se trata de estos últimos, en cuanto se alude a nacionalidad, creencias $u$ "otras circunstancias estrictamente personales» nos enfrentamos a una subespecie de la denigración publicitaria: la denominada publicidad de tono estrictamente personal (Lema, 67), la que siempre y en todos los casos se encuentra prohibida a tenor del segundo párrafo del artículo $11^{\circ}$, que venimos comentando, y del artículo $3^{\circ}$ del decreto legislativo 691 .

Pero la prohibición no es absoluta, al menos al interior del decreto ley 
26122, cuando la propagación de noticias o la difusión de manifestaciones sobre productos, establecimientos, prestaciones, etc., de un competidor, cumple con tres requisitos, a saber: la de ser exactas, verdaderas y pertinentes. Por tanto, una manifestación es desleal cuando no es verdadera y también cuando, siéndolo, es inexacta y no pertinente. Dicho en otra forma, para no ser desleales las manifestaciones o noticias deben ser verdaderas, objeto de prueba por parte de quien las afirma; además, deben ser exactas, lo que supone que la veracidad ha de tomarse en sentido estricto, no cabiendo situaciones parciales; y, por último, deben ser pertinentes, en el sentido de estar directamente relacionadas con el objeto de la información (Otamendi, 152).

Dada la estrecha relación con las normas sobre publicidad, creemos oportuno brevemente señalar algunas similitudes y diferencias. Dentro de las primeras tenemos que el artículo $7^{\circ}$ del decreto legislativo 691 manda que los anuncios, para respetar la libre y leal competencia, no deben denigrar a ninguna empresa, marca, producto, etc., directamente o por implicación. Y según el artículo $3^{\circ}$ ningún anuncio — prohibición absoluta- debe favorecer o estimular cualquier clase de ofensa o discriminación racial, política, religiosa, etc. Más allá, pues, de algunas diferencias de palabras, que pueden enturbiar la interpretación de estos preceptos, puede afirmarse que en los aspectos esenciales hay plena coincidencia. Sobre cuál es la vía procesal - pues cada dispositivo propone la suya - más adecuada, habrá que estudiar el caso concreto y, por lo demás, es análisis que excede con largueza el propósito que nos hemos impuesto en este artículo.

De otro lado, ambas normas, la de publicidad como la de competencia desleal, admiten la exceptio veritatis - tan discutida en el ámbito penal (Peña Cabrera, I, 360 y siguientes) - y la refuerzan con el mandato de sus artículos $15^{\circ}$ y $28^{\circ}$, respectivamente, que determinan que la carga de la prueba corresponderá al anunciante.

Pero no sólo hay similitudes entre ambas normativas en lo que se refiere a la denigración; también se presentan diferencias. En efecto, la ley sobre publicidad no acepta en ningún caso, como sí lo hace la ley sobre competencia desleal, el acto o la conducta denigratoria aunque la alegación sea exacta, verdadera y pertinente. Por tanto, si la alegación publicitaria es veraz, pero sirve para menoscabar el crédito de una persona o empresa, merecerá el calificativo de publicidad desleal (Lema, 67). 


\subsubsection{Actos o conductas que inciden directamente en las posibili- dades de actuación de los participantes en el mercado im- pidiendo el funcionamiento correcto del mismo}

Antes de ingresar a tratar los casos típicos desleales comprendidos en este apartado, creemos oportuno mencionar que dispositivos similares al ofrecimiento de obsequios, premios, etc., que obliguen o comprometan a contratar, así como la venta a pérdida, consignados como supuestos desleales en los artículos $8^{\circ}$ y $17^{\circ}$ de la ley española, fueron eliminados del proyecto que posteriormente se plasmara en el decreto ley 26122 que venimos comentando.

\subsubsection{Actos de engaño}

ARTÍCULO $9^{\circ}$.- Actos de engaño.- Se considera desleal la utilización o difusión de indicaciones incorrectas o falsas, la omisión de las verdaderas y cualquier otro tipo de práctica que por las circunstancias en que tenga lugar, sea susceptible de inducir a error a las personas a las que se dirige o alcance respecto a la naturaleza, modo de fabricación o distribución, características, aptitud para el uso, calidad y cantidad, y en general, las ventajas realmente ofrecidas por los productos o prestaciones.

En especial, se considera desleal ostentar o afirmar la posesión de premios, distinciones, medallas o certificados de cualquier naturaleza que no se han obtenido, o no tuvieran vigencia, particularmente en publicidad o en etiquetas, envases, recipientes o envolturas.

ARTÍCULO $10^{\circ}$.- Actos prohibidos respecto a la procedencia geográfica.- Se considera desleal la realización de actos o la utilización de expresiones que puedan inducir a error sobre la procedencia geográfica de un producto o de un servicio.

En particular, se reputa desleal el empleo de falsas indicaciones de procedencia y de falsas denominaciones de origen, así como el empleo no autorizado de denominaciones de origen, aun cuando se acompañen expresiones tales como tipo, modelo, sistema, clase, variedad u otra similar.

Muchos participantes en la lucha concurrencial creen que es más fácil y ren- 
table, aunque sea incorrecto, introducir productos $u$ ofrecer servicios en el mercado haciendo uso de determinadas técnicas de sugestión para orientar la preferencia de los consumidores, técnicas que no hacen mención a factores esenciales como la calidad y el precio; esas conductas impiden la transparencia en el mercado, que sólo puede alcanzarse cuando la información es veraz y pertinente. A través de los actos de engaño se trata de difundir o utilizar indicaciones susceptibles de inducir a error sobre las ventajas realmente obtenidas, queriendo hacer aparecer como verdadero lo que es falso (Otamendi, 143).

Para que se produzca el acto engañoso, tal como lo señala el artículo $9^{\circ}$ (siendo ello aplicable también al artículo $10^{\circ}$ ), es necesario que se manifieste en la comunicación o difusión dirigida al público, a través de la publicidad o de otra forma de indicación, sea en envases, etiquetas etc., manifestación que puede adquirir cualquier forma escrita o verbal, pero más allá - por cierto- del ámbito de las relaciones interiores de la propia empresa. Todas esas manifestaciones se encuadran dentro de lo que el citado artículo $9^{\circ}$ denomina genéricamente «utilización o difusión de indicaciones» con finalidad concurrencial (Vergez, 54).

Debemos dejar anotado que los supuestos consignados descriptivamente en los artículos $9^{\circ}$ y $10^{\circ}$ asumen una conducta más intencional del agente que la que aparece en otros supuestos de deslealtad, siendo el elemento antijurídico esencial el engaño a los consumidores. Aunque ello no quiere decir, por cierto, que no se cause perjuicio a otros competidores.

Siendo muy extenso el número de supuestos en los que puede recaer el acto engañoso, más que un análisis de los mismos, que sería siempre incompleto, conviene detenernos a ver cuáles son las pautas que deben tenerse presente para valorar cada caso. Siguiendo a Vergez (Vergez, 55 a 57) diremos, en primer término, que para que exista un acto de engaño debe valorársele desde el punto de vista de las características del sujeto que lo sufre, las circunstancias del acto de competencia, el tipo de producto, etc., es decir, determinando el tipo medio de consumidor que hay que proteger. No se trata, a través del acto desleal de engaño, de regular el error vicio en el contrato y de proyectar sobre la figura del consumidor medio la idea del diligente y atento buen padre de familia, cuidadoso protector de sus intereses, pues la práctica pone de manifiesto que lo que prevalece en ese consumidor medio es la falta de atención y ponderación. En segundo término, la valora- 
ción no debe hacerse desde el punto de vista de los contratos efectivamente celebrados, pues, como dice la ley, basta que el acto o la conducta "sea susceptible de inducir a error», obviamente que sobre aquellos aspectos básicos y concretos del producto o de las prestaciones. Una tercera consideración es la relativa al ámbito publicitario o el tipo de manifestación en los que el acto de engaño puede producirse; no resulta siempre sencillo distinguir entre los casos de publicidad superlativa o sugestiva, generalmente tolerados por el consumidor, y el acto de engaño; puede afirmarse entonces que el examen debe efectuarse caso por caso.

Ahora bien, como fluye del propio texto de la ley, es necesario valorar las omisiones o las adiciones que aparecen en las indicaciones engañosas. El engaño por omisión se producirá, por ejemplo, cuando se oculten aquellos datos que son relevantes para tomar una decisión, sobre los que hay obligación de informar y que están relacionados con la naturaleza, modo de fabricación y otras características y ventajas de los productos o servicios. Debe tenerse presente, de otro lado, que una excesiva y muy minuciosa descripción de datos y particularidades no es aconsejable, pues se incluirán muchos irrelevantes que harán olvidar a los verdaderamente importantes y entonces la decisión del consumidor no será probablemente la más adecuada.

El artículo $10^{\circ}$ puntualiza aquellos actos engañosos vinculados a la utilización de expresiones que pueden inducir a error sobre la procedencia geográfica de un producto o servicio. Estos actos están vinculados con las adiciones, no cuando tengan un valor aclaratorio - lo que es lícito y posible- sino cuando son falsas las denominaciones de origen utilizadas, ya que las verdaderas son expresión cabal de una reputación adquirida en el mercado, o también en aquellos casos —usuales en nuestro medio- en los que si bien la procedencia geográfica del producto o servicio es verdadera, viene acompañada de expresiones tales como «tipo», «modelo», «clase», etcétera.

Es del todo pertinente, en nuestra opinión, que el segundo párrafo del artículo $9^{\circ}$ incluya dentro de los actos engañosos a aquellos que afirman la posesión de premios, medallas, distinciones, etc., no obtenidas o que no tuvieran vigencia, y que con cierta frecuencia se encuentran en la publicidad de diarios o revistas, o en etiquetas, envolturas, etc.

Creemos correcto que el artículo $9^{\circ}$ disponga que la inducción a error 
sobre las ventajas realmente ofrecidas de los productos o servicios no tienen que ser necesariamente de tipo económico o de carácter material, sino también de otra clase, como aquellas vinculadas a inversiones, en cuya publicidad se efectúan estimaciones o previsiones de futuro, etc. (Vergez 59-60). Ello podrá ser aplicable, por ejemplo, a la publicidad que efectúan las recientemente creadas Administradoras de Fondo de Pensiones (AFP), cuya regulación publicitaria es, además, específica.

Resulta también de aplicación a los supuestos desleales que venimos tratando lo dispuesto en la legislación sobre protección al consumidor, en especial los artículos $15^{\circ}, 16^{\circ}, 20^{\circ}$ y $24^{\circ}$ del decreto legislativo 716 , los artículos $4^{\circ}, 5^{\circ}, 6^{\circ}, 9^{\circ}$ y $15^{\circ}$ del decreto legislativo 691 sobre publicidad; la Decisión 313 y el decreto Ley 26017 , específicamente en lo que se refiere a las denominaciones de origen. No cabe duda de que en algunos casos resultará difícil determinar a priori cuál debe ser la ley específicamente aplicable o, mejor aún, la más conveniente para los intereses del afectado. Sin embargo, parece claro que un competidor no podrá invocar el decreto legislativo 716 si no es el destinatario final de los productos o servicios a que se refiere el artículo $3^{\circ}$, pero sí podrá hacer uso del decreto legislativo 691 o del decreto ley 26122 .

\subsubsection{Violación de normas}

ARTÍCULO $17^{\circ}$. - Violación de normas. - Se considera desleal valerse en el mercado de una ventaja competitiva ilícita adquirida mediante la infracción de leyes. La ventaja deberá ser significativa.

Éste es un caso típico que no se encontraba antes en la ley peruana y tampoco era común encontrarlo en otras legislaciones. Su incorporación, como veremos, no puede ser más oportuna, pues se trata de una práctica bastante frecuente en nuestro medio.

La infracción de normas legales supone la ruptura de las condiciones de igualdad que deben prevalecer - como hemos dicho ya tantas veces antes- en la lucha concurrencial. Una primera cuestión es determinar si la palabra «ley» limita la infracción a normas de esa categoría o si debe interpretarse como la violación de cualquier tipo de norma, incluso de menor rango, como pueden ser las ordenanzas municipales, siempre que sean 
imperativas. Toda la doctrina española se inclina por esta última posición (Molina, 293; Illescas, 115), la que compartimos, pues la deslealtad no puede depender del rango normativo del precepto vulnerado «sino del hecho de que se obtenga contra derecho una ventaja competitiva» (Otamendi, 183).

Ahora bien, no toda violación de normas por parte del competidor puede ser calificada de desleal; en primer término, la violación ha de reportar una "ventaja competitiva» en relación con los restantes operadores en el mercado que cumplan con la norma violada - representada en una disminución en los costos de producción o distribución de los productos o servicios de que se trate-, o también el acceso privilegiado a un determinado mercado. En segundo lugar, la ventaja mencionada ha de ser «significativa», tal como dice textualmente la ley, pues sólo de esa manera el infractor obtendrá un diferencial de competitividad determinante frente a sus competidores en la lucha por la clientela (Illescas, 115-116). Y, finalmente, el infractor tiene que valerse, es decir, hacer efectiva en el mercado esa ventaja competitiva, más allá de si ello le produce o no una «ganancia» (aunque algunos dicen que «siempre» la obtiene).

Lo que nos parece injustificado e inexplicable es que nuestra ley exija «una ventaja competitiva ilícita», ya que toda infracción legal es de por sí ilícita, salvo que ingresemos al terreno - de suyo importante en el campo del derecho político- sobre cuándo es y cuándo no es lícita la infracción de una norma para proteger un bien superior, discusión que en la vida mercantil y de los negocios no es de fácil admisión.

Los casos clásicos y más comunes subsumibles en este supuesto son los del empresario que opera en la informalidad, en la denominada economía subterránea y sumergida, donde se incumplen en gran medida las reglamentaciones aplicables al ejercicio de la actividad empresarial, especialmente en las áreas del derecho tributario, laboral y de la seguridad social. No es necesario insistir en la magnitud con que aparece esta infracción en nuestro medio, constituyendo hoy un problema de alarmantes proporciones que debe ser enfrentado mediante un conjunto de medidas que rebasan absolutamente a una ley de represión de la competencia desleal, e ingresan al terreno de la política, la economía y la educación.

Para finalizar, nos parece interesante poner de relieve con Illescas (Illescas 114-115) que frente a las infracciones puntuales que caerían bajo el 
artículo $17^{\circ}$, nos encontramos con infracciones permanentes en la legalidad, que más que un acto desleal generan lo que se denomina un estado de competencia desleal, cuyos efectos en el distorsionamiento del mercado suelen ser mayores que el de un acto aislado, y que supone una deslealtad mucho más intensa y perjudicial. Nos estamos refiriendo a todos aquellos casos en que las corporaciones, entidades o empresas públicas han recibido ventajas o incentivos de la más diversa índole, para ser utilizadas con finalidad distinta a la destinada a participar competitivamente en el mercado, ventajas a las que ni siquiera pueden soñar con acceder los competidores. Recordamos aquí el caso de algunas empresas industriales adscritas a las fuerzas armadas que gozaban de significativos beneficios frente a todas las demás, y que en determinado momento decidieron ingresar al mercado con productos que sólo podían suministrar a sus propios institutos, llegando inclusive a copiar o imitar marcas conocidas de propiedad de terceros. Este tipo de actuaciones podrían caer bajo el artículo $17^{\circ} \mathrm{o}$, en todo caso, bajo la cláusula general consignada en el artículo $6^{\circ}$ del decreto ley 26122 .

\subsubsection{Discriminación}

ARTÍCULO $18^{\circ}$.- Discriminación.- El tratamiento discriminatorio del consumidor en materia de precios y demás condiciones de venta se reputará desleal a no ser que medie causa justificada.

La discriminación consiste en tratar de manera diferente a quienes se encuentran en igualdad de condiciones, encerrando con ello un componente de injusticia. La discriminación en el ámbito comercial supone un uso ilegítimo del poder por parte de las empresas.

Resulta entonces por demás sorprendente que este artículo afirme que la discriminación no se reputará desleal cuando exista causa justificada, pues entonces pudiera pensarse que la injusticia puede ser tolerada en algunos casos. Pero como bien dice Ricardo Alonso al referirse al apartado primero del artículo $16^{\circ}$ de la ley española, «no parece que ésa haya sido la intención del legislador, sino más bien el disipar una confusión muy extendida en la práctica que se produce al equiparar discriminación y aplicación de condiciones diferentes... [pues]... sólo cabe hablar de discriminación frente a situaciones de absoluta igualdad de las otras partes que intervienen en el negocio. Así, por ejemplo, aplicar dos precios de venta distintos en función 
de los volúmenes de compra o de los plazos de pago no puede nunca considerarse como un tratamiento discriminatorio» (Alonso, 89).

La ley limita la regulación de la discriminación sólo al precio y condiciones de venta, quizás porque se ha considerado que son los aspectos que plantean los mayores problemas (Alonso, 89). Y el destinatario único es el consumidor, es decir, las personas naturales o jurídicas que adquieren - pues sólo puede tratarse de ventas- como destinatarios finales productos o servicios, definición contenida en el decreto legislativo 716, sobre protección al consumidor, que a falta de otra en el decreto ley 26122 consideramos la más pertinente. Ello significa que se encuentran excluidos los comportamientos discriminatorios con respecto al resto de los operadores económicos, supuestos que pueden caer bajo las normas que regulan las prácticas colusorias o el abuso de la posición de dominio, contenidas en el decreto legislativo 701 .

Ahora bien, si la conducta discriminatoria no justificada ante el consumidor carece generalmente de finalidad concurrencial (Otamendi, 186), debe ser materia de detenido análisis si resultan de aplicación las normas sobre competencia desleal; de lo que no cabe duda es que nos enfrentamos a una conducta claramente reprochable desde la perspectiva del derecho del consumidor. En cada caso deberá evaluarse entonces si resulta más eficaz iniciar una denuncia bajo el ámbito de las normas que reprimen la competencia desleal o bajo el amparo del decreto legislativo 716 .

\subsection{Pequeña cláusula general}

En algunas legislaciones, después del enunciado de aquellas conductas o actos desleales más comunes y dañinos que es conveniente desterrar para lograr una competencia eficaz, es usual incluir una «pequeña cláusula general», en virtud de la cual cualquier conducta o acto similar a los ya enunciados debe también considerarse como desleal. Así se consignó tanto en el artículo $100^{\circ}$ de la ley 13270 como en el artículo $111^{\circ}$ del decreto supremo $\mathrm{n}^{\circ}$ 001-71-IC/DS, antecedentes del decreto ley 26122.

No cabe duda de que la pequeña cláusula general no es imprescindible, dado su carácter reiterativo de la fórmula omnicomprensiva de la cláusula general «grande», en la cual el juzgador encontrará la base para sancio- 
nar un acto o conducta desleal que no se encuentre incluido dentro de los «casos típicos».

La existencia de estas "pequeñas cláusulas generales" puede entonces encontrarse en el propósito «didáctico» del legislador: llamar la atención del juzgador en el sentido de que, además de los actos desleales concretos enunciados, existen otros que le son análogos o asimilables y que, en tanto sean contrarios a las normas de correción mercantiles, deben ser castigados. Si bien jurídicamente innecesaria, tal opción legislativa responde quizás en nuestro medio a la renuencia de nuestros jueces de emitir fallos basados en opciones abiertas como las de las cláusulas generales, bajo las cuales están «obligados a emitir opinión», a ser «creativos», práctica contraria a la cómoda tarea de citar casi textualmente la norma que consideran aplicable al caso concreto que les ha sido sometido.

Dicho lo anterior, debe señalarse que en lo que se refiere a su «pequeña cláusula general» el decreto ley 26122 ha adoptado una posición singular. En efecto, la ubicación de ella no se ha hecho después de los casos típicos desleales enunciados - como es usual - sino al inicio de los mismos, a los que además genéricamente menciona. Preceptúa que todo acto que «por su naturaleza o finalidad pueda considerarse análogo a aquellos que enunciativamente se señalan en el presente capítulo», tales como crear confusión, denigrar, aprovecharse de la reputación ajena, etc., se considera desleal. Las dos cláusulas generales del decreto ley 26122, la "grande» del artículo $6^{\circ}$ y la «pequeña» del artículo $7^{\circ}$, son base amplia y sólida en la que el juzgador encontrará fundamento para sus decisiones.

\subsection{Acciones y procedimiento}

Como el decreto ley 26122 emplea indistintamente como sinónimos los términos «accion» y «denuncia», veamos brevemente el significado que pueden tener. Advertidos sobre la dificultad que significa indagar sobre el significado jurídico de la voz «acción», y sobre las diversas acepciones en su uso cotidiano, digamos, simplificando, que es el medio o instrumento legal para asegurar, a través de un procedimiento, la subsistencia del derecho, impedir su desconocimiento y corregir su violación. Como dice Cabanellas, el derecho sin la acción es pretensión impotente y la acción sin derecho absurdo insostenible (Cabanellas, tomo I, 36). En cuanto a la voz «denuncia», el 
mismo autor dice que es el acto por el cual se da conocimiento a la autoridad de un hecho contrario a las leyes, con el objeto de que ésta proceda a su averiguación y castigo (Cabanellas, tomo I, 619). Los conceptos expuestos sirven, creemos, para entender el significado de «acción» y de «denuncia» en el decreto ley 26122.

A continuación veremos brevemente algunos aspectos del contenido y del trámite de las acciones administrativas o denuncias por competencia desleal y de las medidas cautelares, contenidos en los artículos $20^{\circ}$ y siguientes del decreto ley 26122, que ofrecen al afectado por un acto desleal un amplio abanico de posibilidades, que van desde la pretensión simple de pedir que un acto se declare como desleal, a solicitar su cese o su remoción. Las acciones administrativas se interponen ante el INDECOPI, debiéndose resolver en primera instancia por una comisión ad hoc, quedando agotada la vía administrativa con las resoluciones de su tribunal. Por cierto que las partes - articulo $33^{\circ}$ - pueden impugar judicialmente la resolución emitida por el tribunal.

Bercovitz ha señalado acertadamente que «en materia de competencia desleal, como en tantas otras, son fundamentales los aspectos procedimentales para que la regulación sustantiva sea realmente eficaz. Y hay varias cuestiones relacionadas con el ejercicio de las acciones y el procedimiento que, por su trascendencia en esta materia, tienen que ser mencionadas. En primer término, las acciones ejercitables tienen que ir dirigidas básicamente a conseguir tres finalidades diversas: a) impedir que comience o hacer que cese la actuación que constituye competencia desleal; b) remover los efectos de la competencia desleal ya realizada; y c) resarcir los daños y perjuicios causados. De estas tres clases de acciones, la más importante es, sin duda, la que trata de impedir que se realice o se continúe la actuación de competencia desleal. La razón consiste en que, en la mayoría de los casos, no es posible reparar adecuadamente, a posteriori, las consecuencias dañosas de una competencia desleal. Ello es así porque la competencia desleal afecta a la posición competitiva de una empresa en el mercado, y al ser esa posición competitiva una situación de hecho, no podrá ser nunca restituida por una sentencia. Esa sentencia podrá, en el mejor de los casos, paliar alguno de los efectos perjudiciales. Por eso es también fundamental que la resolución imponiendo la cesación pueda obtenerse rápidamente, por un procedimiento acelerado» (Bercovitz, 11). 
Antes de continuar, conviene aquí hacer mención al problema del fraccionamiento que resulta de la aplicación de diversas leyes vinculadas por la materia - la actividad concurrencial- como consecuencia de los distintos procedimientos que estatuyen, y más aún cuando ellos se ventilan al interior de un nuevo organismo - el INDECOPI - que realiza la actividad jurisdiccional. Estas normas son los decretos legislativos 691,701 y 716 y el decreto ley 26017. No es ésta, sin duda, la mejor forma de afrontar y resolver los problemas que en la realidad del mercado plantean las prácticas competitivas desleales, pues como sabemos son difíciles de disociar de otros supuestos no sólo de competencia desleal, sino también del ilícito publicitario y las infracciones a la propiedad intelectual e industrial. Ésta no es la oportunidad, sin embargo, para profundizar en este importante asunto.

Las acciones por competencia desleal tienen en nuestra legislación el carácter de enumeración cerrada, no así las medidas cautelares, pues el denunciante puede solicitar «cualquier otra», además de las que la ley cita, que ayude a colocarlo en la situación anterior a la realización del acto desleal. Por cierto que las acciones civiles y penales sólo pueden interponerse ante la justicia ordinaria, y ello ha sido objeto de expresa mención en los artículos $31^{\circ}$ y $32^{\circ}$ del decreto ley 26122 , respectivamente.

Por mandato expreso del artículo $26^{\circ}$, al procedimiento le son de aplicación los articulos $173^{\circ}$ y siguientes del decreto ley 26017 , sobre propiedad industrial, y los artículos $486^{\circ}$ y siguientes sobre procedimiento abreviado contenidos en el nuevo Código Procesal Civil, en tanto no desnaturalicen el propósito perseguido por la acción por competencia desleal, de tipo sumario, que persigue obtener una resolución imponiendo la no iniciación o la cesación de la competencia desleal, para poner fin de manera rápida - y a veces definitiva- aquellos comportamientos cuya incorrección es evidente (Bercovitz, 11).

\subsubsection{Legitimación activa}

Según el artículo $20^{\circ}$ del decreto ley 26122 , sólo aquellas personas naturales o jurídicas que han sufrido o pudieran verse afectadas por un acto o conducta desleal podrán interponer las denuncias correspondientes. A diferencia de las normas protectoras de los consumidores (decreto legislativo 716, artícu$\operatorname{los} 4^{\circ}$ y $\left.6^{\circ} \mathrm{f}\right)$ ), y también, aunque en menor medida, de las correspondientes 
a publicidad (decreto legislativo 691 , artículos $1^{\circ}$ y $18^{\circ}$ ), en nuestra normativa sobre competencia desleal sólo se encuentran legitimados para interponer la denuncia en el ámbito administrativo quienes han visto afectados o amenazados sus intereses, los que podrán o no ser -dependiendo de cada caso- empresarios competidores. En nuestra opinión resulta polémico el caso de las asociaciones o entidades gremiales o de otro tipo, en el sentido de si están o no legitimadas para accionar. Creemos que pueden hacerlo sólo excepcionalmente, es decir, cuando como tales se hayan visto o puedan verse perjudicadas por un acto desleal, a pesar de la autorización genérica consignada en el artículo $28^{\circ}$ del decreto ley 25868 , que creó el INDECOPI. Para interponer la acción, por tanto, el perjuicio, o la posibilidad de que ocurra, debe ser directo. En todo caso, nos parece poco viable la sanción de «daños difusos», producidos por ciertas conductas desleales, con base en el decreto ley 26122.

Pero esta opción tiene una singular excepción, que es la posibilidad de que INDECOPI de oficio pueda iniciar la acción. ¿Tiene límites esta facultad de la administración? En nuestra opinión tiene dos, que limitarán grandemente su ejercicio: uno explícito, que es el señalado por el artículo $21^{\circ}$ cuando exige que el acto desleal se encuentre en ejecución; y otro implícito, pues es sólo procedente cuando el inicio de la acción no esté reservado para los competidores; por tanto, INDECOPI actuará de oficio únicamente cuando no se produzcan conductas desleales destinadas a alejar o sustraer directamente la clientela de otro competidor, es decir, aquellos actos que ataquen el funcionamiento concreto del mercado. Este límite viene impuesto por la naturaleza de la norma que venimos comentando, a pesar - repetimos- de la autorización genérica del artículo $28^{\circ}$ del decreto ley 25868 .

De otra parte, la denuncia penal o las acciones de indemnización de daños y perjuicios que puedan iniciarse en el ámbito de la justicia común, sólo serán procedentes cuando las interpongan quienes han sufrido efectiva y directamente los daños resultantes del comportamiento ilícito; no existe, creemos, excepción a esta regla.

\subsubsection{Legitimación pasiva}

Según el artículo $20^{\circ}$ del decreto ley 26122 la denuncia se interpone contra quien haya realizado el acto desleal, y, agregado importante que no existía 
antes en nuestra legislación, contra quien lo haya ordenado; supuesto este último que puede dar lugar a una rica casuística en la que se pueda ventilar, entre otros tópicos, el problema de la responsabilidad mancomunada o solidaria, para el supuesto de pluralidad de agentes de la violación pasivamente legitimados (Otamendi, 208).

\subsubsection{Acciones}

En el artículo $22^{\circ}$ del decreto ley 26122 se juntan, sin distinguirias, las distintas acciones administrativas y las medidas cautelares, todas las cuales son posibles de acumular, tanto por su propia naturaleza como también por mandato del artículo $24^{\circ}$ de la ley. Veremos las acciones, en primer lugar.

\subsubsection{Acción declarativa (artículo $22^{\circ}$ a))}

Mediante esta acción se persigue obtener una resolución que confirme la situación de deslealtad, con el objeto de que no exista duda para calificarla como tal; en otras palabras, se busca producir certeza jurídica. Esta comprobación no implica condena, pues se agota con la declaración administrativa que afirma o niega la voluntad de la ley.

No debemos olvidar que la existencia de un acto de competencia desleal es presupuesto necesario para el ejercicio de otras acciones y, llegado el momento, para pedir la reparación por daños. Ahora bien, dado su carácter secundario, en muy pocas ocasiones esta acción será ejercitada en forma autónoma e independiente, siendo lo usual que se complemente con un pedido de cesación o remoción. Y en este caso la declaración de ilicitud actuará como presupuesto constitutivo de la sanción que se solicita.

Cuando esta acción se ejerce como remedio independiente es porque el denunciante quiere que se reconozca que el acto llevado a cabo por el demandado es uno desleal. «Pero también, como señala la doctrina italiana, $a$ sensu contrario el actor puede solicitar la acción para que quede simplemente "determinado" el que su actividad no es desleal, saliendo así al paso de acusaciones extrajudiciales de otro empresario en las que se solicita por ejemplo el cambio de sus folletos publicitarios por considerarlos susceptibles de confusión. Es la llamada acción declarativa negativa» (Valera, 122), 
que es perfectamente procedente entre nosotros $-y$ no discutible como bajo la ley española-, habida cuenta de que procede incluso cuando ya no subsiste la perturbación que ha creado el acto desleal.

\subsubsection{Acción de cesación (artículo $22^{\circ}$ b) y $22^{\circ} \mathrm{g}$ ))}

Ésta es, sin duda, la más importante de todas las acciones, pues por ella se persigue que el acto o conducta desleal no continúe llevándose a cabo. Ello es así porque la gran mayoría de los actos desleales son continuos y susceptibles de repetirse.

Para dictar la orden de cesación es indiferente que el infractor haya actuado con dolo o culpa, o que incluso se haya producido un daño efectivo, bastando con que el acto ocurra; así, pues, su función no es sólo represiva sino también preventiva. Por ejemplo, carece de lógica hablar de una posible indemnización por daños o de publicar una resolución condenatoria, si no se intenta evitar que el acto se vuelva a repetir.

La cesación puede ser de dos tipos: la provisional y la definitiva; sin embargo, los dos conforman un fenómeno conceptualmente unitario desde el momento en que toda resolución cautelar o provisional está ligada indisolublemente al resultado del proceso. La cesación provisional cumple una función anticipadora y tiende a anular los riesgos provenientes de la duración del proceso, mientras que la definitiva o final se configurará como una orden de hacer o no hacer que la autoridad dirija al denunciado en la resolucion que emita (Valera, 125).

Los presupuestos para solicitar la cesación o prohibición definitiva son, dice Valera, la existencia de un acto de competencia desleal —de ahí la discusión sobre si es aplicable en su fase preparatoria o de tentativa del acto-; el peligro de repetición del mismo; y la irrelevancia de los elementos subjetivos, como el dolo, la culpa o negligencia, ya que la inexistencia de culpa libra de responsabilidad pero no de represión (Valera, 126 a 128).

Cabe aquí hacer mención de que el decreto legislativo 691 sobre publicidad, en su artículo 16.3, contempla dentro de las sanciones la cesación del anuncio publicitario. 
A la cesación provisional y a la prohibición de un acto que no se ha puesto en ejecución les son aplicables las consideraciones de la justicia cautelar, que veremos más adelante.

\subsubsection{La acción de remoción (artículo $22^{\circ}$ e))}

Esta acción tiene por objeto solicitar que la autoridad ordene las medidas necesarias, una vez producido el acto de competencia desleal, para que se eliminen sus efectos a fin de tratar -en lo posible - que el perjudicado vuelva a la situación previa a la comisión de la infracción. Ello se concretará eliminando las cosas u objetos a través de los cuales se ha exteriorizado el acto desleal y cuya persistencia implica una probabilidad de daño, habida cuenta de que el perjudicado estará interesado no sólo en hacer cesar el acto desleal, como pretensión fundamental, sino en que se ordene destruir o remover todo aquello que pueda causarle perjuicio (Valera, 130).

Debe tenerse presente que la orden de remoción se suele solicitar conjuntamente con la de cesación, y que algunos incluso la consideran dentro de una noción amplia de cesación. Pero no debe caber duda de que se trata de peticiones distintas. Si bien ninguna de las dos requiere de la existencia de dolo o culpa por parte del demandado, la diferencia esencial se encuentra en que mientras la acción de cesación se proyecta hacia el futuro, la de remoción se circunscribe únicamente al presente (Valera, 131).

Es evidente que la autoridad administrativa deberá hacer uso de la discrecionalidad que le otorga la ley, valorando los intereses que están en juego, para que al momento de emitir la resolución pueda precisar cuáles son las medidas concretas a llevarse a cabo, las que pueden ir desde la destrucción de envases o material publicitario hasta el cierre temporal del establecimiento infractor, etc., a tenor de lo señalado en el artículo $22^{\circ}$ del decreto ley 26122.

\subsubsection{Acción de rectificación (artículo $22^{\circ}$ f) y $\mathbf{2 3}^{\circ}$ )}

Dada la importancia e influencia de los medios masivos de comunicación, los efectos de los actos desleales no pueden siempre eliminarse o subsanarse decretando únicamente su cesación o su remoción, ni sus consecuencias ser 
compensadas por una eventual indemnización. Es por tal motivo que esta accion persigue incidir sobre los «efectos residuales» que en los empresarios, el mercado o los consumidores ha dejado el acto desleal difundido extensamente.

Ahora bien, esta acción puede revestir dos modalidades: la rectificación de una información incorrecta que denigre a un empresario y la publicidad correctora 0 «contrapublicidad». Según el decreto supremo $\mathrm{n}^{\circ} 005$ 93-ITINCI, la rectificación publicitaria podrá ser publicada, una vez que quede consentida la resolución administrativa, en el diario oficial y en otro a elección del afectado.

El artículo $28^{\circ}$ del decreto ley 26122 dispone que cuando el acto desleal se haya cometido mediante la publicidad la carga de la prueba corresponderá al anunciante, al igual que como lo que señala el decreto legislativo 691 en su artículo $15^{\circ}$. No cabe duda, de otro lado, de que la acción de rectificación guarda similitud con la consignada como sanción en el decreto legislativo 691 sobre publicidad, así como con la indicada en el artículo $175^{\circ}$ del decreto ley 26017 sobre propiedad industrial.

\subsubsection{Medidas cautelares}

El nuevo Código Procesal Civil, por mandato de su primera disposición final, es de aplicación supletoria a todos los demás ordenamientos procesales $\mathrm{y}$, por tanto, también al que estamos tratando, más aún cuando es tan avaro el consignado en el decreto ley 26122. El nuevo código destina un buen número de artículos al proceso cautelar y lo hace con acierto.

Como sabemos, todo proceso puede llegar a demandar un tiempo considerable para su decisión y durante este lapso pueden producirse hechos que hagan difícil y hasta imposible el cumplimiento de lo que se resuelve en la sentencia. De ahí que las medidas cautelares tengan por finalidad asegurar el resultado de la sentencia, y evitar que la justicia sea burlada. El término «medidas», de otro lado, no implica sólo decidir, sino poner en ejecución, cumplir (Martínez, 31). Y no cabe duda de que, desde un punto de vista práctico, la eficacia de las medidas cautelares constituye uno de los mejores parámetros para conocer si la competencia desleal es en verdad efectivamente reprimida. 
La medida cautelar puede ser dictada, a pedido de parte, al momento de presentarse la denuncia o durante el proceso (artículo $68^{\circ}$, Código Procesal Civil; artículo $20^{\circ}$, decreto ley 26122), y a veces de oficio, siempre que se cumplan, al menos, dos requisitos: la existencia de un derecho amenazado por una violación (fumus boni iuris), y el temor fundado de que ese derecho se pueda ver frustrado durante el trámite del proceso, o que la situación del agraviado se pueda ver desmejorada (periculum in mora), lo que llevará a valorizar en la forma más objetiva posible, y antes de concederla, nociones tales como urgencia, inminencia e irreparabilidad.

Un tercer requisito generalmente exigido es la presentación de una «contracautela» por parte del denunciante. La caución procesal -dice Couture - es la seguridad que se otorga en resguardo y garantía del cumplimiento de una obligación derivada del proceso (Couture, 868). Las cauciones, que protegen contra el exceso de protección (Couture, 869), pueden ser de naturaleza real como la hipoteca o de naturaleza personal como la fianza o la juratoria (artículo $613^{\circ}$, Código Procesal Civil). Nacen con ocasión del proceso, subsisten mientras permanezca la razón que las justificó y cesan cuando ésta desaparece, y, como es natural, no se encuentran a merced de la voluntad de las partes, como los contratos, sino de quienes administran justicia.

Ni el decreto ley $26122 \mathrm{ni}$ el decreto ley 26017 , que es de aplicacion supletoria en esta materia por expreso mandato del artículo $26^{\circ}$ del primero, tratan de modo explícito de la «contracautela», que es siempre materia de discusión, pues la medida cautelar se dicta sin oír a la parte contraria. En nuestra opinión puede, sin embargo, ser exigida por motivos tanto doctrinales como normativos. Lo que se persigue con la contracautela es que no se rompa el principio de igualdad de las partes al interior del proceso, ya que una de ellas - la que se ha visto limitada en su poder de disposición o a la que se le ha clausurado temporalmente su establecimiento, etc.puede llegar a sufrir un quebranto de tal magnitud que es necesario asegurarle algún tipo de resarcimiento para el caso en que quede libre de toda responsabilidad al finalizar el procedimiento.

Pero hay también razones con base en disposiciones legales expresas: en efecto, el Código Procesal Civil en su artículo $613^{\circ}$ trata con precisión el asunto, y el artículo $179^{\circ}$ del decreto ley 26017 dice que el denunciante puede solicitar la inspección «por su cuenta y riesgo», lo que podría no tener 
mayor significación, salvo porque el artículo $181^{\circ}$ de ese mismo decreto ley prescribe que el denunciante será responsable por los daños ocasionados al presunto infractor en caso de denuncias maliciosas y negligentes. Así, pues, si bien hubiera sido mejor que el propio decreto ley 26122 regule el otorgamiento de la contracautela, consideramos que existe suficiente base legal para exigirla en aquellos casos en que se considere necesaria.

En un procedimiento por competencia desleal el denunciante podrá solicitar (artículo $22^{\circ}$, decreto ley 26122), por ejemplo, la cesación de un acto desleal, el comiso y la destrucción de etiquetas infractorias, el cierre temporal de un establecimiento y cualquier otra medida (innominadas) que considere necesaria para restituirlo a una situación anterior a la realización del acto desleal. Ahora bien, como lo dice magníficamente el artículo $612^{\circ}$ del Código Procesal Civil, «toda medida cautelar importa un prejuzgamiento y es provisoria, instrumental y variable». En consecuencia, cuando la administración dicte una medida cautelar importará un adelantamiento de opinión, necesario frente a las pruebas aportadas por el afectado, así como para asegurar la ejecución de una sentencia, pero ello no constituirá cosa juzgada pues puede ser variada o revocada dependiendo de los hechos que se descubran y de las pruebas que aparezcan.

En la solicitud o pedido del denunciante para la aplicación de medidas cautelares deberá indicar cuáles son las conductas desleales que lo están afectando - las que pueden estar expresamente consignadas o entroncarse en la cláusula general - o también los actos desleales potenciales siempre que se prevea su inminencia (artículo $20^{\circ}$, decreto ley 26122), no teniendo siempre que justificar el peligro o sus consecuencias, sino únicamente acreditar la existencia objetiva de conductas desleales o de indicios, sin que sea necesaria su materialización. Creemos que es pertinente señalar que las medidas cautelares sólo son viables en tanto los actos desleales se estén ejecutando o exista la amenaza de que se produzcan, pero nunca si ya han sido consumados. En este caso lo que cabrá será una sanción para el infractor, tema que veremos más adelante.

Por mandato expreso del artículo $26^{\circ}$ del decreto ley 26122 , es de aplicación supletoria, en especial en lo que se refiere a las medidas cautelares y las visitas de inspección, lo dispuesto en los artículos $179^{\circ}$, $180^{\circ}$ y $181^{\circ}$ de la ley general de Propiedad Industrial, decreto ley 26017. En el primero se señala la forma en que se planteará la denuncia así como 
las decisiones o medidas cautelares que deben adoptar las autoridades, la verificación de los hechos en el lugar denunciado, y cuando quede fehacientemente acreditada la infracción la adopción de medidas tales como la inmovilización de los productos, la detención del proceso de elaboración o el cierre temporal del establecimiento. En el artículo $180^{\circ}$ se dispone - como es lógico- que la resolución que se dicte deberá pronunciarse sobre la medida cautelar, pudiendo permanecer o ser modificada, aunque la permanencia no podrá sobrepasar a los plazos consignados en el artículo $625^{\circ}$ del Código Procesal Civil.

Ahora bien, nuestro novísimo Código Procesal Civil en sus artículos $682^{\circ}$ y siguientes trata de una medida cautelar excepcional que a nosotros nos interesa sobremanera: la medida innovativa, contraria de la prohibición de innovar tratada en el artículo $687^{\circ}$ del mismo cuerpo legal. Como bien señalan Peyrano y Chiappini, esta medida altera el estado de hecho o de derecho existente antes de la petición de su dictado, la misma que se traduce en una orden de cesación de una actividad contraria a derecho; es decir, ante la inminencia de un perjuicio irreparable (artículo $682^{\circ}$, Código Procesal Civil), ordena que alguien haga o deje de hacer algo en sentido contrario al representado por la situación existente (Peyrano y Chiappini, 476). Persigue, dicen esos autores, «desbaratar la estrategia procesal de los "hechos consumados" (estrategia contra la que nada puede la prohibición de innovar que sólo puede ordenar que no se haga lo que todavía no se ha hecho), que suele desembocar en desigualdades procesales que, a su vez, culminan en "transacciones" leoninas, sólo explicables en función de la posición ventajosa lograda inicialmente (e injustamente) por una de las partes" (Peyrano y Chiappini, 476). Para su dictado, además de los requisitos generales ya vistos para las medidas cautelares en general, se agrega el de la «irreparabilidad del perjuicio», lo que resulta especialmente aplicable a aquellos casos de competencia desleal vinculados en su ejecución a la actividad publicitaria y a los medios masivos de comunicación, o también a los actos de denigración.

Estas medidas innovativas pueden ser dictadas no sólo a petición de parte sino también de oficio según el Código Procesal Civil, con lo que queda cubierto un vacío en la legislación especial. Y resulta de especialísima atención el hecho de que el mencionado código autorice el dictado de medidas cuando la demanda versa sobre el ejercicio abusivo de un derecho, ya que como hemos dicho antes, parte considerable de la doctrina encuentra el 
fundamento para la represión de la competencia desleal en el abuso del derecho de la libertad de competir, constitucionalmente reconocido. $Y$ esto se encuentra ratificado, además, por el nuevo texto del artículo II del título preliminar del Código Civil, que expresamente dispone que cuando el interesado demanda una indemnización u otra pretensión por abuso de derecho puede solicitar medidas cautelares apropiadas para evitar o suprimir dicho abuso.

En relación a esta materia, habrá que ver si en el futuro las autoridades del INDECOPI y después las del Poder Judicial, podrán vencer la renuencia tradicional de los juzgadores para asumir actitudes que si bien consideran justas, pueden - según ellos- constituirse en una peligrosa e ilícita intromisión en la esfera de las libertades de las partes, buscando la verdad formal pero no la material ni la justicia al interior del proceso, o también un exagerado celo -inspirado en un liberalismo que no se practica en ninguna parte- de no entrometerse en la esfera de actividad de los justiciables (Peyrano y Chiappini, 478).

Creemos pertinente recordar que el juzgador deberá decidir en esto de las medidas cautelares con rapidez, sin mayor dilación, pero con toda atención para que no suceda aquello que el magistrado español $R$. Soto cuenta sobre la proliferación de querellas por supuestas infracciones que no tenían otro motivo que el dictado de medidas cautelares durante épocas claves para los respectivos negocios —navidad o temporadas de verano- y que acarreaban un efecto seguro: la ruina y el desprestigio del querellado, aunque luego resultase que la infracción de la que se le acusaba no era tal (R. Soto, $151,152)$.

\subsection{Sanciones}

Una vez determinada o declarada (artículo $22^{\circ}$ a) decreto ley 26122) la existencia de un acto desleal, las sanciones en la vía administrativa son el comiso y la destrucción de los productos, envases, etc. $\left(22^{\circ} \mathrm{c}\right)$ ), el cierre temporal $\left(22^{\circ} \mathrm{d}\right)$ ), todas las cuales se confunden con las medidas cautelares, y principalmente la inscripción del infractor en un registro ad hoc - nos imaginamos que de acceso público-, la publicación de la resolución condenatoria y la imposición de multas. Estas últimas han sido reguladas por el de- 
creto supremo $n^{\circ}$ 005-93-ITINCI, pudiéndose proceder a su cobro una vez que quede consentida o confirmada la resolución respectiva.

La publicación de la sentencia, que constituye una sanción clásica, tiene por objeto que el resultado final de la denuncia se haga llegar a conocimiento de todos los interesados, entre ellos los consumidores. Su efecto sancionador se manifiesta en la repercusión desfavorable que tiene en la credibilidad que ostenta el competidor en el mercado. Esta sanción puede concebirse entre nosotros tanto como una sanción autónoma, como complementaria de otra destinada a reprimir la competencia desleal.

La publicación puede llegar a ser una sanción eficaz, pues tiende a restablecer un orden perdido en el mercado, misión que de suyo es del todo imposible cumplir a cabalidad, tal como lo es atraer el pasado hacia el presente. La publicación puede, teóricamente, hacerse en los más diversos medios: diarios, revistas, volantes, anuncios televisivos, etc. El decreto supremo ${ }^{\circ} 005-93-I T I N C I$ sólo la permite, en nuestra opinión injustificadamente, en el diario oficial y en otro de circulación nacional, desconociéndose las razones por las que se impide hacerla en uno de ámbito local, publicación que en determinados casos podría ser mucho más efectiva.

Se ha planteado en doctrina la discusión respecto a si la parte victoriosa de una controversia puede, a su propio cargo, publicar la sentencia aunque no lo haya así dispuesto el juez. En nuestra opinión no hay inconveniente para ello, siempre que no se denigre a la otra parte y no se alteren u omitan las partes relevantes de la sentencia.

Por último, cabe destacar que en la legislación sobre competencia desleal la publicación es una sanción que tiene que ser solicitada por la parte interesada y la autoridad decidir sobre tal pretensión. Otra es la situación en la normativa sobre publicidad, pues en ella la autoridad tiene la iniciativa, ya que es la que determina cuáles son las resoluciones que deben publicarse, con fundamento en la búsqueda de establecer criterios para la interpretación de las normas en la materia (artículo $24^{\circ}$, decreto legislativo 691).

\subsection{Nulidad}

El artículo $33^{\circ}$ del decreto ley 26122 dispone que con las resoluciones emi- 
tidas por el Tribunal del INDECOPI queda agotada la vía administrativa, pudiendo la parte interesada presentar su demanda, solicitando la nulidad de la resolución correspondiente, ante la Corte Superior de Lima, debiendo tenerse presente lo señalado en los artículos $540^{\circ}$ y siguientes del Código Procesal Civil, en especial lo referente al plazo para la admisibilidad de la impugnación.

\subsection{Prescripción}

En nuestra ley las acciones por competencia desleal prescriben a los dos años de la fecha en que cesó la realización del acto (artículo $30^{\circ}$, decreto ley 26122). Este plazo, que consideramos suficiente, es inferior en un año al señalado en el artículo $21^{\circ}$ de la ley española. A diferencia de ésta, en nuestra ley no hay referencia al cómputo a partir «del momento en que pudo ejercitarse» o desde que «el legitimado tuvo conocimiento de la persona que realizó el acto». Y nos parece adecuada la solución adoptada por nuestra ley, pues si hay alguna fecha más o menos comprobable - aunque ésta será siempre materia de discusión - será aquella en la cual cesó el acto infractor.

Como sabemos, la imposición de un plazo persigue la seguridad jurídica, aunque en ocasiones ello pueda significar un tropiezo en la búsqueda de la justicia.

\subsection{Acción de resarcimiento}

Como se sabe, esta acción civil sólo puede interponerse ante el Poder Judicial una vez que haya finalizado el procedimiento administrativo, tal como lo dispone el artículo $31^{\circ}$ del decreto ley 26122 , en concordancia con lo señalado en el artículo $16^{\circ}$ del decreto ley 25868 , que creó el INDECOPI. Esta acción constituye, para el afectado por un acto desleal, un complemento a la resolución que ha declarado la deslealtad.

Ahora bien, y a diferencia de lo que usualmente sucede en la vía administrativa, para la procedencia de la acción de resarcimiento es necesario que el demandante acredite la intención subjetiva del infractor y el daño causado, así como la relación de causalidad existente entre ambos (ver artículo $1969^{\circ}$, Código Civil). La existencia de una relación de causalidad en- 
tre el acto ilícito y los daños y perjuicios que ocasiona es fácil de entender cuando se trata de daños ocasionados a las cosas materiales, pero este criterio no puede ser llevado al extremo en materia de competencia desleal pues ello podría dar lugar a que se niegue la posibilidad de conseguir el resarcimiento. Por esta razón es que el juez debe actuar con un cierto margen de discrecionalidad y aplicar lo que hace en otras materias, como son los supuestos de daño moral o de violaciones a los derechos a la intimidad, etc., donde tampoco es posible exigir una estricta relación de causalidad entre el acto ilícito y el daño causado (Bercovitz, 12). A este respecto resulta pertinente la exposición de motivos del Código Civil con referencia a su artículo 1984, sobre daño moral (Revoredo, tomo VI, 806).

Otro punto importante es el referente a cuál de las partes debe probar el factor de atribución o culpa. Al igual que lo dispuesto en algunas leyes vinculadas al derecho de la competencia, en las que ya no se exige al demandante sino al demandado que pruebe su actuación, existiendo una especie de presunción iuris tantum de culpabilidad (artículos $13^{\circ}$ y $15^{\circ}$ del decreto legislativo 691 y artículo $28^{\circ}$ del decreto ley 26122), el artículo $1969^{\circ}$ de nuestro Código Civil, en la parte concerniente a la responsabilidad extracontractual, exige también el descargo a quien ha sido el autor de la infracción, el que puede por cierto superar esa presunción y realizar el descargo correspondiente. Como sabemos, no hay responsabilidad con el caso fortuito, la fuerza mayor, el hecho determinante de un tercero, etc. (artículo $1972^{\circ}$, Código Civil).

El autor de la infracción alegará probablemente al interior del proceso que no ha causado daño y que está libre de responsabilidad pues ha actuado en el mercado tratando de atraer o crearse una clientela haciendo «ejercicio regular» de su derecho a competir (artículo $1971^{\circ}$, Código Civil), y el demandante deberá probar que no ha sido así, sino que el infractor ha hecho uso abusivo de tal derecho.

No cabe duda, de otro lado, de que el problema más arduo se encuentra en cuantificar la indemnización económica, que es el núcleo fundamental de la pretensión. Tradicionalmente se ha exigido, para aplicar la sanción, tener presente que el perjuicio resultante del acto o conducta debe ser real, efectivo y evaluable económicamente. Molina señala a este respecto que «para que proceda la indemnización será preciso que se pruebe que existió un daño, es decir, que éste sea real y efectivo, pero no será preciso que sea 
directamente evaluable, puesto que de exigirse este requisito, la indemnización procederá en muy pocas ocasiones debido a la dificultad de la prueba» (Molina, 302). La regla general para la indemnización es la consignada en el artículo $1985^{\circ}$ del Código Civil.

Ahora bien, refiriéndose a este problema de la cuantificación, Bercovitz señala que deben tenerse presente criterios tales como el volumen de negocio de las empresas implicadas con referencia a los servicios afectados por los actos de competencia desdeal, o el beneficio que haya obtenido el infractor gracias a la explotación de un objeto sujeto a un derecho de exclusiva (secretos, por ejemplo). En esta materia creemos que pueden servir de guía al juez algunas de las normas de la ley general de Propiedad Industrial (decreto ley 26017); en efecto, después de señalar en su artículo $184^{\circ}$ que todas las personas que realicen violaciones a derechos de propiedad industrial están obligadas a indemnizar por los daños y perjuicios causados, en su artículo $185^{\circ}$ presenta algunas reglas que pueden servir para evaluar la cuantía del lucro cesante, habiendo antes dejado fuera de duda que el daño emergente también formará parte de la indemnización. Las reglas mencionadas son: los beneficios que el titular hubiese obtenido mediante la explotación del derecho, de no mediar violación; los beneficios obtenidos por el infractor; y la regalía que hubiera debido pagar —digamos, la usual- cuya cifra puede obtenerse de los contratos de licencia cuyo registro es público y, además, obligatorio.

Como ya hemos dicho, son de aplicación supletoria al procedimiento al que da inicio una denuncia por competencia desleal, las normas contenidas en el decreto ley 26017, ley general de Propiedad Industrial, las que están fundamentalmente ideadas para el procedimiento en el ámbito administrativo. El artículo $181^{\circ}$ dispone que el denunciante será responsable de los daños ocasionados al presunto infractor en caso de acciones o denuncias maliciosas o negligentes, el mismo que debe concordarse con el artículo $1982^{\circ}$ del Código Civil, por el cual es procedente el cobro de una indemnización a quien a sabiendas de la falsedad o la ausencia de motivo razonable denuncia a una persona atribuyéndole la comisión de un hecho punible. En la práctica, creemos que será más fácil para las autoridades administrativas que para las judiciales saber cuándo el denunciante se encuentra en la situación descrita, mas la interrogante es la siguiente: ¿puede el INDECOPI, específicamente su tribunal, imponer esa indemnización, o será preciso acu- 
dir a la justicia común? Si creemos que se trata de una situación en la que deberá necesariamente apreciarse la intención subjetiva y el daño causado, así como la causalidad existente entre ambos, entonces deberemos aceptar que la procedencia y el monto de la indemnización sólo se podrán determinar en el Poder Judicial.

Si bien el decreto ley 26122 no señala plazo de prescripción para la interposición de la acción por resarcimiento, el Código Civil sí lo hace en su artículo $2001^{\circ}$, inciso 4 ), determinando que aquella acción prescribe a los dos años contados a partir del día en que ella puede ejercitarse (artículo $1993^{\circ}$ ). Por su parte, la ley general de Propiedad Industrial es más específica, pues en su artículo $183^{\circ}$ dispone que la prescripción ocurre a los dos años de expedida la resolución administrativa condenatoria. En nuestra opinión esta última es la única interpretación posible, ya que el artículo $31^{\circ}$ del decreto ley 26122 sólo permite la interposición de la acción por resarcimiento después de agotada la vía administrativa.

Un aspecto no contemplado en nuestra ley es el referente a lo que puede ocurrir si una vez dictada la sentencia indemnizatoria el acto desleal es repetido, lo que es perfectamente posible que suceda. En Alemania e Italia la jurisprudencia ha establecido la condena a una suma como liquidación del daño para las futuras violaciones (Molina, 303). No siendo posible utilizar esta vía entre nosotros, debiera estudiarse la posibilidad de que la reincidencia del acto se considere como una desobediencia al juez, siendo de aplicación las normas pertinentes.

\subsection{Acción penal}

A diferencia de lo que ocurrió en sus inicios, hoy día es asunto aceptado que la competencia desleal debe ser considerada fundamentalmente un ilícito civil. Es más, ciertas experiencias legislativas en sentido contrario han demostrado ser muy poco eficaces. Por cierto que ello no puede invalidar el cuestionarse si la represión tal como está hoy diseñada es suficiente y si, apreciados los intereses que deben tutelarse y el objeto de la disciplina, no sería conveniente valerse, para determinados actos desleales, de sanciones de índole penal, que tienen una mayor fuerza y eficacia represiva, ingresando de esa manera al terreno de los delitos económicos o al de los delitos contra los derechos intelectuales. 
Aunque esta discusión excede en mucho el propósito de este artículo, la inclusión de nuevas figuras delictivas vinculadas con el fenómeno de la competencia económica en el nuevo Código Penal de 1991 nos obliga a efectuar una breve referencia. Concepción Molina argumenta a favor de la penalización de ciertos actos desleales de la forma siguiente: el bien jurídico protegido por la disciplina de la competencia desleal no es otro que los principios concurrenciales derivados del sistema económico constitucionalizado, es decir, la libertad, la igualdad y los propios mecanismos de mercado; bien jurídico protegido que tiene como objeto la «competencia operativa», concretándose en el interés que tiene el Estado en el mantenimiento del «orden público económico» así como en los intereses de todos los participantes en el mercado. Ante ello, el derecho penal — continúa - no puede ser mero receptor de los valores constitucionales, no puede contentarse con la protección de intereses generales, sino que debe concretamente perseguir penalmente determinadas conductas desleales (Molina, 357 a 359).

La modalidad de competencia desleal más antigua que se criminalizó, y que todavía se encuentra en algunos códigos, fue la de los ataques a la propiedad industrial, específicamente la falsificación e imitación de patentes y marcas (artículos $222^{\circ}$ a $225^{\circ}$ de nuestro Código Penal), para posteriormente introducirse otras figuras tales como el engaño publicitario (artículo $238^{\circ}$, Código Penal), engaño en las prestaciones (artículo $239^{\circ}$, Código Penal) o el aprovechamiento indebido de la reputación ajena (artículo $240^{\circ}$, Código Penal). A ello se suma el más tradicional referente a la violación del secreto profesional (artículo $165^{\circ}$, Código Penal) o los más novedosos correspondientes a los delitos contra los derechos de autor (artículos $216^{\circ}$ y siguientes del Código Penal). Desgraciadamente, no sabemos si la introducción de estas figuras delictivas, algunas nuevas entre nosotros, son el reflejo de una opción consciente y meditada del legislador, en el sentido que representan una respuesta y reconocimiento de la importancia que tienen las infracciones en el terreno del derecho de la competencia. Lo que sí puede afirmarse es que esta incorporación hará necesario estudiar atentamente la eficacia de la aplicación de las sanciones habituales en el campo penal, pues con alta probabilidad demostrarán ser insuficientes o inadecuadas en muchas ocasiones al comportamiento delictivo. Y también traerá a discusión el asunto de la responsabilidad penal de las personas jurídicas y de los nuevos métodos necesarios para facilitar pruebas de las conductas desleales.

El decreto ley 26122 en su artículo $32^{\circ}$ prescribe que antes de dar ini- 
cio a la acción penal por los delitos que ahí se señalan y que hemos mencionado líneas arriba, el fiscal deberá solicitar un informe técnico a la autoridad administrativa, la misma que deberá evacuarlo en el plazo perentorio de cinco días hábiles, para ser presentado al juez penal. Conociendo nuestra realidad judicial en el ámbito penal, puede decirse que el artículo $32^{\circ}$ es del todo apropiado, ya que la especialización de las autoridades administrativas será un importante apoyo en la búsqueda de un fallo justo, y hará posible abreviar el trámite y dejar sentado algunos aspectos que el fiscal o juez penal promedio no están en la mejor disposición de conocer. Por otro lado, las recomendaciones que pudieran existir en ese informe no tienen carácter obligatorio, por lo que la majestad del proceso penal no queda resentida.

\subsection{Modelo de competencia subyacente}

Revisada nuestra ley, consideramos pertinente hacer mención, siguiendo a Bercovitz (Bercovitz, 9,10,11), a cuál es el modelo de competencia que subyace a la enumeración de los supuestos concretos prohibidos que hemos antes visto. Y seguimos al destacado jurista español, pues esta reflexión la hace sobre la parte sustantiva de la ley española que es en la que la nuestra se inspira.

Conocer el modelo de competencia subyacente nos servirá para entender mejor la regulación legal y además para interpretar mejor la cláusula general delimitatoria de la competencia desleal. Las características del modelo son las siguientes: en primer término, la claridad y diferenciación de las ofertas, ya que sólo de esta manera podrá el cliente potencial compararlas y elegir entre ellas; por tal motivo se prohíben todos los comportamientos destinados a engañar o a confundir, pues son contrarios al objeto de conseguir transparencia en el mercado. En segundo lugar debe partirse de la premisa que la actuación de los oferentes en el mercado debe basarse en su propio esfuerzo, sin apropiarse del esfuerzo de los demás competidores; es por este motivo que, si bien se acepta la imitación de iniciativas empresariales ajenas que pueden considerarse útiles de integrar a las propias ofertas, salvo en lo que lesione o infrinja un derecho exclusivo - ya que ello es característico del sistema competitivo-, lo que no puede aceptarse es la reproducción de ofertas u obras rivales sistemáticamente (a través de medios técnicos, por ejemplo), o la explotación de secretos empresariales obtenidos por violación del factor de confidencialidad. Exigir que la actuación del operador econó- 
mico se base en su propio esfuerzo significa que éste debe dirigirse a mejorar sus ofertas, más que a atacar a los competidores. Ésta es la razón por la que se prohíbe la denigración o la inducción a la infracción contractual. En síntesis, los agentes económicos deben conseguir su autoafirmación en el mercado mediante la captación de clientes basada en la bondad de sus ofertas.

Un tercer principio consiste en la exigencia de que los agentes económicos cumplan la legalidad vigente, pues sólo de esa manera se puede competir en condiciones de igualdad. Si un empresario formal debe competir con informales se encontrará en clara situación de inferioridad pues sus costos serán superiores; situación que se agrava cuando el Estado, sea a través de una repartición pública o de una municipalidad, no impone el respeto a las leyes. Un cuarto principio lo halla Bercovitz en que a los operadores económicos se les prohíbe la arbitrariedad en su actuación en el mercado, lo que implica que no puede discriminarse entre los clientes o imponerles condiciones abusivas; por tal razón, se prohíbe - bajo otro tipo de normas- el abuso de la posición dominante, aunque ésta se refiere al conjunto del mercado y no a una clientela cautiva como es el caso de la competencia desleal. Y, por último, el principio más importante y evidente es el de garantizar la libertad de decisión de los consumidores, principio sobre el que en verdad se basa todo el sistema competitivo de economía de mercado. De esta forma toda actuación que impida o limite la decisión libre de los consumidores es, en principio, incompatible con el modelo que trata de proteger la regulación sobre competencia desleal; de lo que se sigue que aquellas conductas agresivas que tratan de imponer a los consumidores la realización de ciertas operaciones constituyen actos de competencia desleal.

\subsection{Reflexión final}

El funcionamiento de una economía de mercado y de un modelo de «competencia operativa» responde a un conjunto de variables de la más diversa índole; entre ellas se encuentran la adecuación de las normas legales a la situación concreta del país, la aceptación por parte de los ciudadanos de que se trata de reglas que es conveniente cumplir, y, también, la decisión política de aplicar y hacer acatar tales normas. Estos tres aspectos esenciales tienen, en nuestro país, un signo de interrogación frente a la normativa sobre la competencia desleal. 
En primer término, porque la normativa que ha adoptado el Perú, siguiendo el modelo español, que a su vez ha sido tomado del contexto europeo, responde a un desarrollo económico y social que nos es ajeno y a una evolución jurídica sólo parcialmente compartida. En segundo lugar, porque en una nacion en formación como es el Perú, en la que conviven diferentes culturas y etnias, es probable que las escalas de valores que la sociedad y el individuo aceptan como suyas no tengan simetría, y sean para algunos cuestionadoras de verdades que para otros son aceptables. En tercer lugar, porque el Estado peruano, los juristas y el «establishment» no se han interesado verdaderamente por los aspectos de la deslealtad en el comercio, salvo - por cierto- cuando se han sentido de alguna forma afectados.

La reciente promulgación de un muy importante conjunto de normas para hacer posible la «modernidad» y hacer funcional la economía social de mercado, puede quedar en un intento frustrado más, de los muchos que se han producido en la historia de la República, si no se realiza en diversas áreas un esfuerzo grande de comprensión, pero también de adaptación. La deslealtad en el comercio es un viejo y permanente problema que toda sociedad comparte, pero todos no entienden lo mismo por desleal ni todos los países aciertan al diseñar las herramientas para combatirla. Es probable que se haya iniciado ya y que se incremente durante los próximos años un combate económico y jurídico entre la regla de conducta que la norma legal prescribe y las pautas que los consumidores y productores aceptan como válidas. Todos los participantes en el mercado y el propio Estado debieran hacer un esfuerzo para conocer en profundidad los términos de ese debate y - quizás más animados de lo que hoy están- para participar en él. Casi todo lo demás, por ahora, cae en el terreno de las meras opiniones y hasta en el de la imaginación. 


\title{
Bibliografía
}

\author{
ALONSO, Ricardo
}

1992 «Supuestos de competencia desleal por venta a pérdida y discriminación», en La regulación contra la competencia desleal en la ley de 10 de enero de 1991, coordinador Alberto Bercovitz, Cámara de Comercio e Industria de Madrid, Madrid.

ASCARELLI, Tullio

1970 Teoría de la concurrencia y de los bienes inmateriales, Bosch, Barcelona.

BAYLOS, Hermenegildo

1978 Tratado de Derecho Industrial, Ed. Civitas, Madrid.

BERCOVITZ, Alberto

1992 «La competencia desleal», en Derecho de los Negocios, Año 3, $N^{\circ} 20$, Madrid.

CABANELLAS, Guillermo

1972 Diccionario de Derecho usual, 3 tomos, Ed. Heliasta, Buenos Aires.

COUTURE, Eduardo

1955 «Caución procesal», en Enciclopedia Jurídica Omeba, tomo II, Ed. Bibliográfica Argentina, Buenos Aires.

DE LA CUESTA, José María

1992 «Supuestos de competencia desleal por confusión, imitación y aprovechamiento de la reputación ajena», en La regulación contra la competencia desleal en la ley de 10 de enero de 1991, coordinador Alberto Bercovitz, Cámara de Comercio e Industria de Madrid, Madrid. 
DIEZ CANSECO, Luis José

1991 «Señora: nuestro detergente lava más blanco. La publicidad comparativa», en Themis, Revista de Derecho, $\mathrm{N}^{\circ} 18$, Lima.

FONT GALÁN, Juan I.

1987 Constitución económica y derecho de la competencia, Ed. Tecnos, Madrid.

GALÁN CORONA, Eduardo

1992 «Supuestos de competencia desleal por violación de secretos», en La regulación contra la competencia desleal en la ley de 10 de enero de 1991, coordinador Alberto Bercovitz, Cámara de Comercio e Industria de Madrid, Madrid.

GHIDINI, Gustavo

1975 «La competencia desleal. Desde las corporaciones al corporativismo», en Revista de Derecho Mercantil, $\mathbf{N}^{\circ} \mathbf{s}$. 135136, Madrid.

GÓMEZ SEGADE, José Antonio

1974 El secreto industrial. Concepto y protección, Ed. Tecnos, Madrid.

ILLESCAS O., Rafael

1992 «La infracción inducida de contratos y de normas como acto de competencia desleal», en La regulación contra la competencia desleal en la ley de 10 de enero de 1991, coordinador Alberto Bercovitz, Cámara de Comercio e Industria de Madrid, Madrid.

\section{LEMA DEVESA, Carlos}

1992 «Supuestos de competencia desleal por denigración y comparación», en La regulación contra la competencia desleal en la ley de 10 de enero de 1991, coordinador Alberto Bercovitz, Cámara de Comercio e Industria de Madrid, Madrid. 
MARTÍNEZ BOTOS, Raúl

1990 Medidas cautelares, Ed. Universidad, Buenos Aires.

MENÉNDEZ, Aurelio

1988 La competencia desleal, Ed. Civitas, Madrid.

MOLINA B., Concepción

1993 Protección jurídica de la lealtad en la competencia, Ed. Montecorvo, Madrid.

OTAMENDI, Juan José

1992 Competencia desleal, Ed. Avanzadi, Pamplona.

PEÑA CABRERA, Raúl

1992 Tratado de derecho penal, 2 tomos, Ed. Jurídicas, Lima.

PEYRANO, Jorge y CHIAPPINI, Julio

1986 «Medida innovativa», en Enciclopedia Jurídica Omeba, apéndice V, Driskill S.A., Buenos Aires.

REVOREDO, Delia (compiladora)

1985 Código Civil. Exposición de motivos y comentarios, Lima.

SOTO, Rodolfo

1992 «Las medidas cautelares en los procedimientos de competencia desleal», en La regulación contra la competencia desleal en la ley de 10 de enero de 1991, coordinador Alberto Bercovitz, Cámara de Comercio e Industria de Madrid, Madrid.

VALERA, Sol Bacharach de

1992 «Acciones derivadas de la competencia desleal», en La regulación contra la competencia desleal en la ley de 10 de enero de 1991, coordinador Alberto Bercovitz, Cámara de Comercio e Industria de Madrid, Madrid. 
VÉRGEZ, Mercedes

1992 «Competencia desleal por actos de engaño, obsequios, primas y otros supuestos análogos», en La regulación contra la competencia desleal en la ley de 10 de enero de 1991, coordinador Alberto Bercovitz, Cámara de Comercio e Industria de Madrid, Madrid. 